\title{
TERROR IN UTOPIA: CRISIS (MIS-) MANAGEMENT DURING THE COVID-19 PANDEMIC IN SWEDEN
}

'Mirror, mirror on the wall, which is the most humanitarian country of them all?'

\begin{abstract}
This article provides an early account to document Swedens strategy to the COVID-19 pandemic and critically examines the countrys crisis response during the first six months of 2020. Sweden stood out internationally with a hands-off approach that gained much attention. Schools remained open, no lock-downs were underaken, no face masks reccommended, even in care homes, and testing-tracing-isolation was very limited. Although Swedens death rate per million was among the seven highest in the world during the period, there was no change in strategy. The article employs concepts to analyse and understand this peculiar approach and the secutity culture and political culture underpinning it. It uncovers deeper systemic defects and a breakdown in the state functions accompanyied by secrecy and cover-ups, as well as a totalitarian element in the political culture.
\end{abstract}

Keywords: Sweden; COVID-19; pandemic; strategy; security culture; totalitarian democracy

\section{Introduction}

Sweden has often been portrayed as an international model of solidarity, social welfare and humanitarianism ${ }^{2}$. In the United States, for example, it has been upheld both as a model, often for the Democrats at least since the Kennedy administration, but also as a conformist social prison ${ }^{3}$. Swedish foreign policy has itself been aimed at promoting

1 jcs@stilhoff.se

2 I would like to express a special thankyou to the Science Forum Vetcov-19 group of scientists in Sweden for continuous discussion on a range of issues on the subject. Available online: http:// vetcov19.se/ (accessed on 17 July 2020).

3 Susan Sontag's essay "A Letter from Sweden” published in Ramparts Magazine, July 1969 (pp 23-38) portrayed Sweden in the latter negative image, just as some of Donald Trumps speeches have done. 
Sweden as a model, at least since Olof Palme, the Social Democratic Prime Minister assassinated in 1986. During the Cold War, its neutrality policy accompanied a vision of a 'third way' in global politics. As a highly export-dependent country such images of Sweden as a role model, an image and utopia, have served an economic purpose and continued to be cultivated in post-Cold War times. It has projected itself as a humanitarian superpower, whether through foreign aid or Europe's most liberal refugee policy, and it has propagated a feminist foreign policy with norms of egalitarianism that it aims to spread to the world. During the first half of 2020 and the pandemic of COVID-19, such (self-) images of Swedish exceptionalism took a hard toll.

The crisis response and management adopted by Sweden during the COVID-19 pandemic in spring 2020 stood out as remarkably different from any of its neighbouring countries or for that matter in Europe and the world. While the crisis response differed globally, notably between and within European and Asian regions, the Swedish path was still sufficiently singular to merit considerable international media attention and deserves closer scrutiny. An analysis of the wider social effects and consequences at the time of writing (midJuly 2020) may seem premature and a thorough evaluation would have to wait until after the first and possibly second wave of the pandemic is over. Nevertheless, it is still both possible and important to analyse the crisis response during the first six months and wave of the pandemic, spanning the period from the discovery of the outbreak in January until July 2020. This article sets out to do that by critically examining the strategy and the dynamic between the Swedish government and relevant authorities, medical experts, and the Swedish public during this initial period. The aim is to understand Swedish society and security culture by narrowing in on how it functions during a particular crisis and the focus will be on analysing the communication and regulations proposed or not proposed by the authorities and its ramifications and reception in the population. Written during the midst of this period (early summer 2020) there has for most of the events and policies been little or no secondary literature to draw on. The sources consist of a range of material including 'soft sources' such as statements in press conferences or to media, interviews in media and news reports, but also government agency reports. With regards to 'soft sources' such as news media, these have been various established mainstream media and all information has been double-checked or traced further when deemed relevant, such as for example with some whistle-blower statements. As this virus is new, there are very few academic books or papers published that would add much at this stage. Literature relating to other pandemics is informative to a degree but, as others have identified, this particular virus has some novel aspects and is not yet fully understood, including the phenomena of cluster formation. In future years much more will no doubt be known. With regards to questions of virology and medicine, new findings have been reported in medical journals or by health agencies on daily basis, and the production of new research has been fast. Their character have varied from peer-reviewed or pre-view journal papers, from double-blind studies to meta-analysis, behavioral or cohort studies, to reports from health agencies. The speed of new findings most relevant to the policy analyzed here has been especially related to the issue of preand asymptomatic spread, the question of aerosol spread, the question of the utility of face masks, the question of children and the disease and hence the role of schools in the spread

Conversely, for some Democrats and social liberals, Sweden has sometimes been used as a model. 
of the virus, and reports about medical long-term effects of the virus. As a non-physician the author has continuously discussed findings and new updates within a Science Forum (Vetcov-19) consisting of a few dozen (mainly) Swedish physicians, including virologists and epidemologists. While obviously not a main focus, the virology and medical aspects have been an important backdrop and this reference group has been highly valuable.

There is an extensive literature on public health frameworks and their management, various responses to pandemics, but it is beyond the scope of this article to engage fully with these. Comparisons with the rest of the world can be made only to an extent, but in order to do this fully many variables need to be taken into consideration (population density, age distribution, cultural behavioral patterns, such as previous mask wearing habits, possibly the climate, and several other factors.) Future comparative studies, including diachronic or cross-country comparisons will be important to bring further understanding to the Swedish case. Here, the focus is rather on the developing situation in Sweden as it emerged and was experienced, the choices that the Government and the public health agency made early on and which continues. Some comparative observations are made with other Nordic countries, which it might have been expected would experience similar levels of infection/death if similar directives had been employed, where appropriate. In describing and analyzing ongoing events, some theoretical concepts are introduced and explained as they become relevant, such as 'new public management' reforms and their relation to crisis preparedness in the Swedish case, and with regard to some critical observations on Swedish nationalism and peculiar characteristics of the Swedish state and political culture. Some concepts are presented as pedagogical critical devices rather than being theoretical.

\section{Sweden: a path of its own}

Following the official declaration by the COVID-19 pandemic by the World Health Organisation (WHO) on 11 March 2020, most European countries initiated various levels of lockdown and school closures during March ${ }^{4}$. Italy had already started this on 9 March and closed their schools on 5 March. All other Nordic countries were quick to initiate lockdowns and close schools, bars and restaurants as well as their borders for non-citizens or residents, beginning with Denmark on 14 March, Norway on 16 March and Finland on 18 $\mathrm{March}^{5}$. They also initiated contact-tracing and isolation of cases.

Sweden, by exception, only temporarily closed the gymnasiums (which were re-opened on 16 June) and moved to on-line university teaching, while all schools remained open. Initially Britain and Sweden followed the same path aiming at mitigation (or "herd immunity"), but on 16 March Britain abandoned this strategy claiming it had been based on miscalculations and would cost too many deaths before being achieved ${ }^{6}$. Sweden continued

4 For example: Italy 9/3, Spain 14/3, Austria 16/3, France 17/3.

5 Coronovirus (COVID-19) in the Nordics-statistics and facts. Available online: https://www.statista. com/topics/6123/coronavirus-COVID-19-in-the-nordics/\#dossierSummary_chapter6 (accessed on 29 June 2020)

6 The term "herd immunity" (a layman term for "mitigation") was not officially used and often denied, but as will be argued below the strategy can be inferred from the actions taken or not taken. The state epidemiologist Tegnell stated on 17 March that they (the FoHM) did not use the term, but that they looked at Britain and that it was something like herd immunity Sweden needed to arrive 
with its own strategy of openness. In general, there were no restrictions on travel or movement, no testing and tracing, no recommendation of face masks even in hospitals or care homes, or other similar measures that began to be implemented across Europe. There was a limit set on gatherings to first 500 people (12 March), and then 50 people (29 March) ${ }^{7}$. Restaurants, bars, shops, clubs, remained open with some exceptions. The FoHM recommended hand washing and keeping a social distance, and to stay home from work or school in case of symptoms like fever. The strategy, discussed further below, while unclear and sometimes officially denied, seemed to be opting for herd immunity by allowing a slow spread among the population while protecting the risk groups and keeping the pace of the spread at a level so as to not overburden the healthcare system. As discussed below this was never clearly stated and there was much confusion around it, so the strategy rather has to be interpreted and inferred from the actions taken or not taken.

In Europe it was only Belarus that pursued a similar path. However, in Belarus although schools remained open it was not mandatory and parents who had the ability to keep their children at home could do so. The central and regional authorities in Belarus also had stronger recommendations with regards to protective measures in public spaces ad in schools since the end of April. In Sweden, by contrast, even parents belonging to risk groups and patients with confirmed COVID-19 had to send their children to school and risked being fined if they did not do so.

While Swedish experts warned about a pandemic already in January this was dismissed by the authorities and often ridiculed in media ${ }^{8}$. Although there was dissent and critique within the medical and scientific community the strategy seemed to have a general support in the population, as will be analysed in a separate section on nationalism further below.

at: P. J. Larsson Anders Tegnell hyllar Brittisk tanke kring flockimmunitet: "Dit vi behöver komma". Available online: https://www.aftonbladet.se/nyheter/a/6j7vaO/anders-tegnell-hyllar-brittisk-tankekring-flockimmunitet-dit-vi-beh (accessed on 17 March 2020); in an interview to Nature on 21 April he stated that "each country has to achieve herd immunity": Paterlini, M. "Clother borders is ridiculous": The epidemiologist behind Sweden 's controversial coronavirus strategy. Available online: https://www.nature.com/articles/d41586-020-01098-x (accessed on 14 July 2020). For the strategy in Northern European countries see: Caracciolo, B (2020) "How the Mitigation Strategy tempted Northern Europe and Convinced only Sweden”, Medium, 17 July 2020. Available online: https://medium.com/@barbara.caracciolo2020/how-the-mitigation-strategy-tempted-northerneurope-and-convinced-only-sweden-f6fb9197d49a (accessed on 17 July 2020).

7 Government decision 11 March (in effect from 12 March). Available online: https://www. regeringen.se/artiklar/2020/03/forordning-om-forbud-mot-att-halla-allmanna-sammankomsteroch-offentliga-tillstallningar/

And decision of 27 March (in effect from 29 March). Available online: https://www.regeringen. se/artiklar/2020/03/forbud-mot-allmanna-sammankomster-eller-offentliga-tillstallningar-medfler-an-50-deltagare/

8 For example, Björn Olsen, Professor of Infectious Diseases at Uppsala University, warned about a coming pandemic in January. On 14 April 22 scientists from a variety of disciplines spanning from epidemology and virology to mathematics and bio-statistics, warned about and pleaded for a change of the Swedish strategy. They were widely dismissed and discredited in the media and by the Swedish Public Health Authority (FoHM). 
Except for the Sweden Democrats (a national-conservative party), who continuously raised critical questions in the Parliament, most political parties gave passive consent until around May when they began voicing critique as the death-rate had risen to among the highest in Europe. By 30 April Sweden ranked among the top ten in the world with the highest deaths in COVID-19 per million, with a ratio of 244, or about seven times higher than neighbouring Finland and Norway (ourworldindata.org 30 April). By early June it had risen to twice as many deaths in Sweden as the neighbouring region of all other Nordic countries, all Baltic countries, Poland, and Kaliningrad combined. By 8 July Sweden had reached a ratio of 538 deaths per million inhabitants exceeding for example the U.S., which had 394, by nearly forty percent (ourworldindata.org). Meanwhile, and contrary to some assumptions, the economy was just as badly affected as in countries pursuing lockdown'. Indeed, Swedish unemployment remained higher than the EU average and higher than in the other Nordic countries or in Germany.

When the Nordic countries reopened their borders to each other in June, Sweden was excluded. Finland, Denmark and Norway, but also the U.K kept restrictions against travellers from Sweden who would have to spend time in quarantine. The Czech ministry of health assigned Sweden as the highest risk zone in the E.U (Pirodsky, 2020). Sweden had become a massive disease hotspot and epicentre in Northern Europe.

As time pulled on and the death toll rose, Sweden's path stood out as even more peculiar. Face masks were not even mandated in hospitals or care homes for those working with suspected or confirmed COVID-19 cases (Schneider, 2020). It was only on 25 June, 2020, and after more than 5000 deaths, that the Swedish FoHM recommended that face masks or protection should be used in hospitals and care homes, but even then only in connection with confirmed or suspected cases ${ }^{10}$. In other words it took the Swedish Public Health Agency over six months, in the midst of a pandemic, to recommend mask and face shield to all health-workers in contact with confirmed covid19 patients ${ }^{11}$. But with regards to the public and for all other hospital workers not dealing with COVID-19, the Swedish authorities and state epidemiologist still insisted on discouraging the use of face masks, even as scientists worldwide warned about the virus being airborne and that face masks provide protection ${ }^{12}$.

9 Svensk coronastrategi ingen ekonomisk vinnare: https://www.sydsvenskan.se/2020-06-10/svenskcoronastrategi-ingen-ekonomisk-vinnare (accessed on 10 June 2020).

10 FoHM Press Conference 25 June 2020 (Svt Nyheter).

11 It should be noted that many hospitals nevertheless used face masks for personnel in contact with infected, but it was local decisions and varied considerably between regions and clinics.

12 In an interview to DN on 27 June the state epidemiologist Tegnell advised against public use of face masks. Available online: https://www.dn.se/nyheter/sverige/anders-tegnell-landernasoppnande-ett-gigantiskt-experiment/. While research had proved their effectiveness, for example: Face masks for the public during the COVID-19 crisis. Available online: https://www.bmj.com/ content/369/bmj.m1435 (accessed on 9 April 2020), and file://C:/Users/Jens/AppData/Local/ Microsoft/Windows/INetCache/IE/2VQZNNGF/PIIS0140673620311429.pdf and file://C:/Users/ Jens/AppData/Local/Microsoft/Windows/INetCache/IE/J3QJWM8W/dp13319.pdf. In early July 239 scientists from 32 countries wrote a letter to the WHO warning that the virus is airborne: Jee C. A group of 239 scientists there's grooving evidence COVID-19 is airborne. Available online: 


\section{The Sovietization of the Swedish state}

What was the Swedish strategy, and was there one? When analysing the Swedish strategy, it is first important to note a peculiarity with regards to responsibility and accountability within the Swedish public sector. The Swedish government, the Prime Minister and Minister of Health were conspicuously absent from the public scene during much of spring 2020. For months the Prime Minister gave no interviews, only delivered some pre-recorded messages, and no crisis group was formed in the Parliament. The responsibility for managing the crisis was divided in an unclear manner between the Public Health Agency (FoHM) with its Director General (Johan Carlsson) and State Epidemologist (Anders Tegnell), and between the regions and municipalities responsible for healthcare, elderly care and schools respectively. Other agencies were also involved, such as Socialstyrelsen (The National Board on Health and Welfare) which oversees the medical profession and the civil contingencies agency MSB. The precise location of responsibility for an issue remained obscure. The Government (Prime Minister and Minister of Health) claimed that they had no competence on pandemics or medical issues and therefore referred to the FoHM and the state epidemiologist. With regards to responsibility over deaths in healthcare and elderly care, both the FoHM and Government referred to the regions and sometimes the municipalities. It was the twenty-four regional authorities that were responsible for equipment, crisis preparedness, as well as for the healthcare. The municipalities were responsible for the care homes, as was the private companies running them. The individual hospitals and care homes in turn referred back to the FoHM regarding advice on routines to follow, face masks and other equipment. Hence, a circle was completed when FoHM claimed they were not responsible for clinics or care homes, whereas the latter referred to FoHM for any routines, rules or regulations they followed or did not follow.

The situation with an evasive accountability structure was complicated by the practice of secrecy and lacking transparency in the Swedish state. On a formal level the Swedish constitution and laws regulating the administration guarantees transparency of public agencies, municipalities and regions, so that journalists or an individual citizen can get access to documents and even internal correspondence unless it has been specifically denoted as confidential in a decision with specific reference to a legal paragraph ${ }^{13}$.

However, the models and assumptions used by the FoHM were not made public, so it was not possible for the research community or public to scrutinize them. Instead they had to rely on the information presented at the daily press briefings that started to be held at $2 \mathrm{pm}$. A daily ritual was established, with the FoHM and state epidemiologist offering statement and although followed by questions by journalists no critical questions would be asked by any of the (mainly Swedish) journalists present. Few questioned the lack of transparency or requested the models or assumptions behind the "strategy". FoHM did not publish their code until 24 April (and corrected it on 26 April).

https://www.technologyreview.com/2020/07/07/1004841/a-group-of-239-scientists-say-theresgrowing-evidence-COVID-19-is-airborne/ (accessed on 7 July 2020).

13 This means that the default condition is public access and transparency, and that a particular document in order to be classified has to be denoted as such with a specific motivation and legal reference, for example with regard to the classification act (Sekretesslagen) or individual privacy. 
Secrecy and lack of transparency was a more general pattern. The regions did not share information that they had about the spread of the disease to the municipalities in the regions. The municipality Staffanstorp took the Skåne region to administrative court in order to receive the information for the municipality (and won the case). Basic and middle schools often refused to give any information about whether a student or parent was diagnosed with COVID. Often the teachers were also kept uninformed. In Sörmland, near Stockholm, some municipalities kept secret the number of deaths in care homes, and on the regional level higher officials kept secret and planned to cover up death rate figures for the region ${ }^{14}$. Uppsala, Sweden's fourth largest city, covered up or refused to make public the number of infected in care homes (Sveriges Radio, 16 Juni). Also in Uppsala, the management of the university hospital (Akademiska Sjukhuset) kept secret that COVID-19 was spreading in the maternity ward ${ }^{15}$.

The trust in the state strategy and FoHM's recommendations was not shared by all. Sweden's largest trade union Kommunal, which organises half a million workers on municipal and county level doubted the government and FoHM's claim that no face masks or protective equipment was needed when treating COVID-19 patients, and following the spread of COVID-19 at the care home Serafen in Stockholm, they initiated a blockade or work stop $^{16}$. Kommunal argued with reference to the Swedish work environment law and to protect their workers, not the elderly living in the care home. The case was taken to the Swedish Work Environment Authority, who ruled in favour of Kommunal ${ }^{17}$. This in turn led to a lobbying campaign by Swedens Municipalities and Regions (Sveriges Kommuner och Regioner), a political interest organisation for the municipalities and regions with obscure status, against the Swedish Work Environment Authority (SWEA). Lacking face masks and basic equipment in the regions, they feared the decision would become a precedent and therefore wished SWEA to reverse the decision, which is also what happened ${ }^{18}$. The fact that the regions and municipalities on a political level exercised pressure on the authorities to abandon recommendation of protective equipment when working with COVID-19 patients in care homes would eventually be taken up by some editorials as a threat to the trust in institutions in Sweden (Pihl, 2020).

14 Various articles in Eskilstinakuriren: se 2/5-20 "Professorn starkt kritisk till kommunernas mörkläggning”. Available online: https://ekuriren.se/artikel/wjo397yj and 8/6-20 Efter mörkläggningen - kommunerna får bakläxa”. Available online: https://ekuriren.se/bli-prenumerant/artikel /8rxxg38r

15 Förlossningen vid Akademiska Sjukhuset drabbades av smittspridning ledningen la locket på. Available online: https://www.svt.se/nyheter/lokalt/uppsala/forlossningen-vid-akademiskasjukhuset-drabbades-av-smittspridning-ledningen-la-locket pa?fbclid=IwAR0OGjOTZ7iyhc1z vBJnB6NalJdrEDLhfXE9gJtFgTcx0eJJlTmadL2pVQw (accessed on 17 May 2020)

16 Kommunal: "Vi fortsätter lägga skyddsstop". Available online: https://www.svt.se/nyheter/lokalt/ stockholm/kommunal-vi-fortsatter-lagga-skyddsstopp (accessed on 14 April 2020)

17 Ewald, H. Kommunal får rätt $\urcorner$ - munskydd och visir ett måste. Available online: https://www. dn.se/sthlm/kommunal-far-ratt-munskydd-och-visir-ett-maste/ (accessed on 8 April 2020)

18 SVT avslöjar: kommunernas intresseorganisation fick myndigheter att tona ned munskyddskrav. Available online: https://www.svt.se/nyheter/inrikes/svt-avslojar-kommunernas-intresseorganisation-fick-myndigheter-att-tona-ned-munskyddskrav (accessed on 29 June 2020) 
By 18 June Sweden had a growth in new cases that was fifteen times higher than the six surrounding Nordic and Baltic countries combined ${ }^{19}$. In reaction to the media beginning to report on lacking competence and crisis preparedness despite the Governments claim to the contrary, the FoHM began to keep all minutes with meetings with the regional medical officers (smittskyddsläkare) secret already from 17 March onward ${ }^{20}$. Again, this was in principle a violation of the transparency of Swedish public agencies as regulated in the Constitution.

A pattern started to become visible with secrecy, cover ups and manipulation of information at state, regional and municipal levels.

After SWEA:s downplaying of the role of face masks was leaked to the media, SWEA began a cover up by erasing emails requested by journalists ${ }^{21}$. The same practice was used by the Region Sörmland in order to hide inconvenient information from journalists ${ }^{22}$.

While in violation of Swedish law this practice has become relatively common (Wålsten, 2020). Indeed, this practice is so developed that we can speak of the emergence of a "Shadow Management" in Sweden, and there is little reason to fear any legal sanctions since the Swedish legal system typically does not sanction power holders (Sörensen \& Olsson, 2020). Ultimately this undermines the Swedish constitution, especially (Offentlighetsprincipen, "the Principle of Openness", and Regeringsformen, "The Instrument of Government"), and the core infrastructure of the democratic state.

Thus, the pandemic began to reveal a more systemic problem within the Swedish state, a pattern of secrecy, cover up, and of evasive accountability, or what we with a political analogy might refer to as "sovietization".

\section{Hypothesis of a strategy}

As already mentioned, and as will be discussed further in the next paragraph, there was no clearly communicated strategy from the Swedish government or relevant authorities and the models and assumptions used by the FoHM were not made public. Instead numerous evasive and contradictory statements made it difficult to establish what was actually the aim. However, the strategy - if it can be labelled such - can be inferred from the actions taken or not taken. Sometimes it was also confirmed by public officials, although later denied or contradicted by other officials.

19 Sweden had 1,239 new cases, Denmark 44, Norway 20, Finland 5, Estonia 2, Latvia 6, and Lithuania 2 (see Yaneer Bar-Yam, endcoronavirus.org 18/6).

20 Minskad insyn hos FHM - mötesanteckningar hålls hemliga. Available online: https://www.svt. se/nyheter/inrikes/minskad-insyn-hos-fhm-motesanteckningar-halls-hemliga (accessed on 1 June 2020).

21 Myndigheten ville slippa "svår debatt" om munskydden - framgår av mejl som raderats. Available online: https://www.svt.se/nyheter/inrikes/kritiserade-myndigheten-ville-slippa-svar-debatt-ommunskydden-framgar-av-mejl-som-raderats (accessed on 30 May 2020) and Efter granskningen: Personal på Arbetsmiljöverket uppmanas radera mejl. Available online: https://www.svt.se/ nyheter/efter-granskningen-personal-pa-arbetsmiljoverket-uppmanas-radera-mejl (accessed on 8 June 2020).

22 Regiondirektörens mejl kastade - kan vara tjänstefel. Available online: https://ekuriren.se/bliprenumerant/artikel/elwdw11r 
I here hypothesize that the strategy was to achieve herd immunity and that this was based on the following assumptions by FoHM:

1. COVID-19 is a "like a flu" and behaves like a flu (this assumption was incorrect since it does not behave like a flu. For example, the spread is not even but characterised by a cluster pattern, and age distribution and age mortality are different).

2. Most people will eventually get it, so there is no use trying to stop it, which was stated publically by former state epidemiologist and FoHM advisor Johan Giesecke, as well as the disease control officer of Norbotten ${ }^{23}$. Moreover, for $98 \%$ of the infected it would be harmless and not even noticeable ${ }^{24}$.

3. Hence, it was best to try to mitigate it and protect the system from being over-burdened. And, to protect risk groups, especially care homes. However, it should be noted that Anders Tegnell and FoHM knew about the lacking capacity in the care homes, with problems related to both regulations, staffing, organisation, and even stated this publicly ${ }^{25}$.

Thus, whereas the Italian model was to stop the infection, Sweden (as the UK until $16 \mathrm{March}$ ) wanted the infection to spread, but to special groups and at a manageable pace. However, spread was an aim. If people get infected, they get immune (again this has turned out to be uncertain, so a bold and dangerous assumption) and cannot infect others. This is the essence of herd immunity achieved without vaccination and was an idea spread in Northern Europe and based on lessons from the Spanish flu (Caracciolo, 2020). The aim seemed to be an ideal balance of entry-exit numbers in the hospitals.

Schools should therefore be kept open, based on another assumption, that children don not become particularly sick and do not infect others (again partly incorrect). Thereby the schools could be used to spread the disease evenly through society, and if the spread needs to slow down the "tap" can be turned off by closing them. Hence, schools are a regulator for disease transmission towards herd immunity.

Now, regardless this was an intended strategy or not, it is what the Swedish state was doing. But it must be assumed that herd immunity was the goal otherwise none of the actions makes sense, such as: a) the open schools, b) the insistence on not recommending face masks and even go to some length as preventing it by claiming their use is counterproductive (people will get more sloppy if believing in masks etc,) and that it could even

23 This was often and most explicitly stated by former state epidemiologist Johan Giesecke, who served as advisor to FoHM and made regular interviews explaining "our strategy" (FoHM's), for example on Swedish state television: Svt Morgonsoffan 28 May 2020. Available online: https:// www.svt.se/nyheter/inrikes/giesecke-det-ar-inte-sakert-att-ett-vaccin-kommer-vara-effektivt; On a Press conference on 31 March the disease control officer for the Region Norrbotten stated explicitly that the goal (at least for the region) was "herd immunity".

${ }^{24}$ Giesecke interviewed on state television 6 May 2020: Giesecke: Det är inte säkert att ett vaccin kommer vara effektivi. Available online: https://www.svt.se/nyheter/inrikes/giesecke-det-ar-intesakert-att-ett-vaccin-kommer-vara-effektivt (accessed on 17 July 2020).

25 On 7 June the Director General, Johan Carlsson, claimed that the lacking capacity in the care homes in Sweden had been well known for years and had been established by three consecutive governmental inquiries: Carlsson till motattack mot Åkesson. Available online: https://www. aftonbladet.se/nyheter/a/4qMzlq/carlson-till-motattack-mot-akesson (accessed on 17 July 2020). 
increase the spread, all without empirical backing or evidence and eventually, by June, in direct contraction with evidence ${ }^{26}$.

By April, the unclarity about what the Swedish government and authorities were aiming at led the epidemiologist Carina King to suggest she felt she was being gaslighted by the authorities. An editorial by Ivar Arpi in the main daily Svenska Dagbladet discussed this on 15 May (Arpi, 2020). The term gaslighting comes from the famous Alfred Hitchcock movie "Gaslight" (1944) starring Ingrid Bergman. It involved a deliberate strategy by a husband to convince his wife to believe she was insane.

\section{Gaslighting}

By April, the Swedish authorities seemed to be engaged in a game of gaslighting the population. Reasonable questions were dismissed, critical researchers or physicians were portrayed as heretics, and contradictory statements were repeatedly made.

The most fundamental aspects here are:

a) the unclear location of responsibility,

b) the unclarity and contradictory statements about what the strategy was,

c) misleading statements about protection equipment, such as face masks,

d) misleading statements about pre- and asymptomatic infection,

e) convincing the population that the rest of the world had taken erroneous steps and that they eventually would receive the same death rates as Sweden, or alternatively that comparisons were not meaningful,

f) aiming to discredit any critique or scientific evidence not fitting the FoHM statements.

Some of these points have already been mentioned, such as the ambiguity of the location of responsibility and the misleading statements about protection equipment. Ambiguous statements were continuous throughout spring and summer 2020, both from the government (Prime Minister, Minister of Health) and the main operator FoHM. For example: on 13 March the state epidemiologist Tegnell proclaimed that the new strategy was to not do any testing or contact tracing as there was no point in this and it was not important to know how many people were infected (Karlsson, 2020). This was at the same time as Norway moved into lockdown. However, this was contradicted in June, when there was a considerably wider spread, and on 26 June the Government instructed the FHM to resume the testing ${ }^{27}$. Sweden, the government claimed had now entered a "late phase of the pandemic"28. However, when this statement was made the number of actively infected

26 As late as 14 July, when most other countries had introduced face masks, and the British PM gave a speech on face masks being required in public spaces in the UK, the Swedish FoHM argued the opposite. FoHM:s spokeswoman Karin Tegmark Wigsell claimed that the use of face masks had increased the spread of disease in other countries, hence suggesting that other countries got it wrong and in fact had counter-productive recommendations: Utökad karantän kan bli aktuell - och kanske mynskydd. Available online: https://www.aftonbladet.se/nyheter/a/kJ24jv/utokadkarantan-kan-bli-aktuell--och-kanske-munskydd-i-vissa-fall

27 Some testing had taken place throughout, but it was very limited to hospitalised patients and some health workers.

28 Press meeting with the PM, 4 June 2020. Available online: https://www.regeringen.se/pressmeddelanden/2020/06/presstraff-med-statsministern-4-juni/ (accessed on 4 June 2020) 
was increasing, from 27,879 on 2 June to 32,731 on 8 June, hence an increase by $17.5 \%$. To claim this as a decrease and a late pandemic phase simply made no sense. It also made no sense to claim that testing was pointless in March, when the infection rate was lower, but suddenly meaningful in June.

The indifference to test- and tracing and resistance to lock-down was in line with the insistence on keeping the schools open and mandatory, even for those in risk groups. It was regularly claimed that children do not infect others and that closing schools would have no impact on the spread of the virus, in contradiction to increasing evidence and reports of teachers dying in Sweden and children being admitted to hospital. The Director General of FoHM, Johan Carlsson, claimed this on 13 March and added that it would be inappropriate to close schools, since the children would have nowhere to go (Fernstedt, Karlsson, 2020). Many doubted this reasoning, and following an individual confirmed case of COVID-19 at the school Campus Manilla in Stockholm in early March the principal decided to temporarily close the school. It was particularly sensitive since the Crown Princess daughter was attending the school. The state epidemiologist was upset by this and worried that other school headmasters might follow; he wanted to ensure a prevention of school closings by issuing instructions to the regions (Delin, 2020).

The unfolding of the school issue left many parents in risk groups or with children in risk groups, exposed to either catch the virus or if they kept their children at home, of being fined for violating the school law.

The issue with open schools and discouraging the use of face masks support the hypothesis that herd immunity was the strategy, even if contradictory and often confusing statements were made related to this. Regional disease control officers (Smittskyddsläkare), who were in weekly contact with FoHM, were occasionally outspoken. The disease control officer for the region Norrbotten. Anders Nystedt, claimed as late as 5 April that herd immunity was the strategy and presented the aim in a power point (Nyberg, 2020). The state epidemiologist himself often gave guesses as to when herd immunity might be achieved in the country or in the capital Stockholm, with various dates suggested at various times ${ }^{29}$. When neighbouring countries closed their borders in mid-March he argued against this as an erroneous strategy (Svahn, 2020). The former state epidemiologist, Annika Lindhe (state epidemiologist 2005-13), argued in early March that herd immunity, and allowing the disease to spread slowly through schools and the healthy adult population, would be a desired strategy (Linde, 2020). She would later change her mind, but argue that this is what the Swedish strategy seemed to be.

Most outspoken on herd immunity was Johan Giesecke, former state epidemiologist (1995-2005) and employed as advisor to FoHM, and a mentor or close affiliate of the state epidemiologist Tegnell. Giesecke gave interviews in various international media, stating that herd immunity was the only reasonable strategy (Russell, 2020; Quann, 2020; Hardy, 2020; Sayers, 2020). Giesecke, a senior to Tegnell, was often presented in the media as a Swedish authority and a Nestor on epidemiology.

29 For example: Ellyatt H. Sweden resisted a lockdown, and its capital Stockholm is expected to reach "herd immunity" in weeks. Available online: https://www.cnbc.com/2020/04/22/no-lockdownin-sweden-but-stockholm-could-see-herd-immunity-in-weeks.html (accessed on 28 April 2020) and https://sv.wikiquote.org/wiki/Anders_Tegnell\#Januari 
While Tegnell and Giesecke both gave regular estimates in the media with regards as to when herd immunity could be achieved, it was simultanously denied that this was a strategy. On 15 March, Karin Tegmark Wisell at FoHM stated in Swedish Radio that herd immunity was not the strategy, and that the aim was to stop the virus ${ }^{30}$. Meanwhile, the state epidemiologist Tegnell said that the idea of herd immunity is "partly correct" but not the strategy ${ }^{31}$. Further, on the 16 May, on one of his few live press conferences, The Prime Minister denied that herd immunity was the strategy: "let me also underline that there is no Swedish strategy to create herd immunity in response to this COVID-19. Herd immunity is a status (sic), not a strategy"32. Hence, with all the public talk of herd immunity and when it might be achieved, with open schools and no face masks, it was difficult to distinguish between this being a deliberate strategy or just an assumed inevitable end state. The claim instead was to protect the risk groups, but this in turn seemed contradicted by the negligence of protection equipment in hospitals and care homes and by denying elderly in risk groups oxygen, as we shall return to below. In the end, the goal may have been to protect the hospital system and the economy.

On 16 June, the disease control officer (Smittskyddsläkare) for Stockholm stated that people who had had COVID-19 could still go to work if they had only mild symptoms (Larsson, 2020).

Another case of misleading the public came with regard to PCR tests and antibodies, where FoHM first gave the impression that COVID-19 spread rapidly and widely through the population, while only really affecting a small number, and spreading the unfounded assumption that a considerable number had already had the disease (Bränden, 2020a). In the same manner FoHM mislead the public with regard to how many had developed antibodies and achieved immunity (Bränden, 2020b). According to a media inquiry the FoHM communication was in contradiction with basic immunological knowledge (Bränden, 2020c).

A final illustration of gaslighting is with regards to obscuring responsibility or completely denying it. Despite thousands of deaths in care homes the Prime Minister proclaimed it had nothing to do with the Swedish strategy ${ }^{33}$. There was in fact no governmental responsibility for this whatsoever. In July, the Director General of FoHM, Johan Carlsson, made the claim that what had happened in Sweden with, as of 8 July, more than seven times deaths per million than all other Nordic countries combined, was all a matter of chance and bad luck ${ }^{34}$. He also claimed that any comparison with other Nordic countries was meaningless, and he dismissed their strategies as unfounded ${ }^{35}$.

30 Strategin: Ska bromsa corona - till varje pris. Available online: https://www.expressen.se/nyheter/ strategin-lat-manga-smittas-i-lagom-takt/ (accessed on 15 March 2020).

31 Strategin: Ska bromsa corona - till varje pris. Available online: https://www.expressen.se/nyheter/ strategin-lat-manga-smittas-i-lagom-takt/ (accessed on 15 March 2020).

32 Expressen Live TV 16 May 2020: Här pressas Löfven om corona av utländska joutnalister. Available online: https://www.expressen.se/tv/nyheter/coronaviruset/har-pressas-lofven-av-utlandskajournalister-om-corona/ (accessed on 16 May 2020).

33 Prime Minister interviewed in SVT Agenda, 14 June 2020.

34 Jani Pirttisslo Sallinen Carlsson: Slump att Sverige Drabbades. Available online: https://www.svd. se/carlson-coronadrabbat-sverige-var-en-slump (accessed on 10 July 2020).

35 Jani Pirttisslo Sallinen Carlsson: Slump att Sverige Drabbades. Available online: https://www.svd. se/carlson-coronadrabbat-sverige-var-en-slump (accessed on 10 July 2020). 
At a press conference on 14 July, a CBS journalist asked the FoHM spokesperson Karin Tegmark Wisell about the strategy in light of Sweden's high death rate, around forty percent higher than the United States, and received the answer that country comparisons were not meaningful at this stage ${ }^{36}$.

The Director General, state epidemiologist and consultant Giesecke dismissed the strategies pursued by other countries, especially the Nordic neighbours, claiming that every country eventually would have the same death rates ${ }^{37}$.

The message to Swedes was that all other countries handled this wrong and that only Sweden had the correct analysis. The message was reinforced in an interview on 16 July by the Prime Minister, who stated that the Swedish strategy to handle the corona disease was "completely correct" (Johansson, 2020).

\section{Oxygen or Morphine?}

In April a Swedish MD and District Doctor, Jon Tallinger, labelling himself Dr. Whistleblower, claimed that recommendations had been given to Physicians to administer morphine instead of oxygen for elderly people in care homes, effectively implying active euthanasia $^{38}$. The triage also meant that patients over eighty years old, or over sixty-five if they belonged to a risk group, should be denied IC treatment to preserve space in the IC units ${ }^{39}$. While Tallingers claim was denied by officials it was supported by another whistleblower,

36 https://www.svtplay.se/video/27534853/nyheter-direkt/myndigheternas-presstraff-om-coronalaget -4 ? start=auto (38 mins into the program). (Accessed on 17 July 2020).

37 Again Giesecke was the most outspoken on this, dismissing other countries strategies: Giesecke: Om ett år är övriga Norden i kapp Sveriges dödstal. Available online: https://www.dn.se/nyheter/ sverige/giesecke-om-ett-ar-ar-ovriga-norden-i-kapp-sveriges-dodstal/ (accessed on 10 May 2020) An assumption supported by an academic Professor Jan Albert: Lär bli jämna dödstal I Nordens länder. Available online: https://omni.se/professor-lar-bli-jamna-dodstal-i-nordens-lander/a/ xP2dJ8 (accessed on 10 May 2020), whereas the State epidemiologist Tegnell claimed Sweden had better measures and statistics than any other country: Tegnell: Därför har Sverige högre dödsfall (accessed on 11 April 2020). Available online: https://www.svt.se/nyheter/inrikes/ tegnell-darfor-har-sverige-hogre-dodstal and Berg Eidebo J. Tegnell: Därför har Sverige högre dödsfall (accessed on 11 April 2020). Available online: https://www.gp.se/nyheter/sverige/tegnelld\%C3\%A4rf\%C3\%B6r-har-sverige-h\%C3\%B6gre-d\%C3\%B6dstal-1.26674362. On 21 May the state epidemiologist Tegnell claimed that Swedish tourists would be safer for other countries to receive during the summer, since Swedes would have a higher level of herd immunity: Scogelin M. Tegnell: svenska turister kan vara säkrare än andra. Available online: https://www.svd.se/tegnellsvenska-turister-kan-vara-sakrare (accessed on 21 May 2020)The Director General Johan Carlsson claimed that the death rate in Sweden had nothing to do with strategy, but was completely down to chance: Svenska Dagbladet. Available online: https://www.svd.se/carlson-coronadrabbat-sverigevar-en-slump

38 Available online: https://www.youtube.com/watch?v=Csb9DvAUj_s (accessed on 8 July 2020) and https://www.youtube.com/watch?v=xk0TK_Syn9I\&t=592s (accessed on 8 July 2020).

39 On a press conference 26 March, Thomas Linden, from the leadership group of the Swedish National Board of Health and Welfare (Socialstyrelsen) explained which patients could eventually come to be denied treatment: "Bräckliga personer kan snart nekas coronavård". Available online: https://www. exakt24.se/brackliga-personer-kan-snart-nekas-coronavard/ (accessed on 26 March 2020). 
a nurse, Latifa Löfwenberg who also claimed that at least ten people had died as a result of the Regions Gävleborg guidelines (Eriksson, 2020). After going public with her claim, she was fired from her position. While the Swedish media initially ignored Tallingers claims, he went on to present them on youtube with backup interviews and by going through patient journals ${ }^{40}$.

On 18 May, Yngve Gustavsson, a professor of geriatric medicine at the University of Umeå, warned in the Swedish medical journal that many elderly died unnecessarily as they were kept in the care homes and not admitted to hospital and therefore were not given the correct medical assessment or treatment ${ }^{41}$.

In April and May the Health and Care Inspectorate (IVO) began investigating the situation in Swedish care homes ${ }^{42}$. On 20 May IVO stated that a larger investigation was initiated following both IVO:s own observations and reports of elderly not being administered oxygen treatment. On 7 July IVO reported a complete national overview and that a few regions had made initial assessment that elderly should not be sent to hospital care regardless of being in need, but instead be kept in the care homes ${ }^{43}$. However, with the scaling up of capacities the practice had been abandoned.

By July several similar incidents had reached international media. On 7 July a Finish nurse who had been working in Sweden told the newspaper Yle that the deaths of elderly had been speeded up in Sweden with doctors prescribing morphine and entry into a stage of palliative care, sometimes even without meeting the patients ${ }^{44}$. She also confirmed the claims that patients were also denied oxygen. A practice of denying IC care for patients over eighty years was further taken up in the media, with the case of an eighty-one year old man who had been denied IC care although there was available space in the hospital (Erlandsson, 2020). On 16 July CBS News broadcasted an interview from Stockholm with a woman whose eighty-year old father living in a care home had been diagnosed with COVID-19, but instead of being sent to hospital he had been given morphine and eventually died without treatment ${ }^{45}$.

${ }^{40}$ For example here: Available online: https://www.youtube.com/watch?v=LeMSieNQwUQ (accessed on 8 July 2020).

41 60. Läkartidningen (Swedish Medical Journal) 18 May: Ohlin E. Geriatrik professor: Många äldre dör i unödan utan korrekt bedömning. Available online: https://lakartidningen.se/aktuellt/ nyheter/2020/05/geriatrikprofessor-manga-aldre-dor-i-onodan-utan-korrekt-bedomning/

42 IVO 20 May, 2020: Tillsyn av vård och behandling på landets samtliga särskilda boende för äldre. Available online: https://www.ivo.se/publicerat-material/nyheter/2020/tillsyn-av-vard-ochbehandling-pa-landets-samtliga-sarskilda-boenden-for-aldre/ (accessed on 17 July 2020).

43 Tillsyn av vård och behandling på landets samtliga särskilda boende för äldre. Available online: https://www.ivo.se/publicerat-material/nyheter/2020/ivo-fordjupar-granskningen-av-vard-ochbehandling-pa-sarskilda-boenden-for-aldre/ (accessed on 17 July 2020).

44 Available online: https://yle.fi/uutiset/3-11433976 (with excerpts in Swedish here: Sverige bilden. "I Sverige har äldre människors död påskyndets med morfinsprutor"). Available online: https:// meritwager.nu/allmant/sverigebilden-i-sverige-har-aldre-manniskors-dod-paskyndats-medmorfinsprutor/) (accessed on 9 July 2020).

45 CBS News 16 July. Available online: https://www.cbsnews.com/video/sweden-sees-high-virusmortality-rate-after-resisting-lockdown/ (accessed on 17 July 2020). 
In mid-July, during the ongoing national overview by IVO, about one of five regions (Sweden has 21 regions), reported to IVO that palliative care had been put in place prematurely during the early stage of the pandemic and that decisions for it had been general rather than individual ${ }^{46}$.

\section{Disallowing protective equipment}

Aside of not having face masks or protective equipment, several care homes in Sweden had incidents with removal of existing equipment, such as hand disinfection or banning private use of face masks. Staff in one care home in Stockholm reported that hand disinfection was kept locked in and only allowed to be taken out in case the media visited ${ }^{47}$.

An elderly woman living as a resident in a care home in the municipality of Götene reported to Swedish radio that she wanted to protect herself by using her own private face mask, but was prohibited by the staff from doing so with the argument that it looked scary ${ }^{48}$.

\section{The experience of terror in every-day life}

In his classical text on international security studies Barry Buzan outlined the state itself as a potential source of threat to individual security (Buzan, 1983). Taking the individual, and people, as the irreducible basic unit to which security applies, it is clear that the state can be both a shield providing security and a threat to it. In a Hobbesian sense the state can prevent anarchy, provide social stability, law and order, and physical protection, but on the other hand the state can also intervene in ways that diminish individual security. An aspect of individual security is social threats, those that arise from the fact that people are embedded in a human environment (Buzan, 1983, p. 19). Concepts like weak states, state fragility, or failed states, refer to conditions where the state fails or is unable to provide basic security, health or social services. But the state can also generate insecurity by exposing or targeting individuals, minorities, or citizens, or in the worst cases become an instrument of terror.

For many citizens in Sweden insecurity became a real experience during spring 2020 as their everyday life became subject to a biopolitical experiment allowed by the state. A consequence of the measures and conditions discussed above was for parts of the population an experience of anxiety and fear in everyday life. This was induced as much by the strategy and actions taken or not taken, as it was by the pandemic itself. For elderly people living in care homes or utilising the municipal home care / domestic service, daily visits by caretakers without face masks implied a potential visit by the angel of death. The caretakers too were in an exposed position, not allowed protective equipment on their daily rounds. Anxiety related to these services by extension affected caring relatives. The ultimate terror

46 Dagens Nyheter 18 July 2020: Flera regioner: Palliativ vård sattes in för snabbt. Available online: https://www.dn.se/nyheter/sverige/flera-regioner-palliativ-vard-sattes-in-for-snabbt/ (accessed on 18 July 2020).

47 Expressen, 17 May 2020: Larm från boendet: "Vi tigger för att få handsprit". Available online: https://www.expressen.se/nyheter/coronaviruset/larm-fran-boendet-vi-tigger-for-att-fahandsprit/

48 SR (Swedish Radio) 15 May 2020. 
was of course in relation to the news of triage and the denial of IC care for certain age or risk groups. Suddenly trust in healthcare was in question.

Similar distress was experienced by teachers and parents in risk groups, who were forced to work in or send their children to school. This too implied a daily decision and balancing between breaking the law and the risk of becoming infected. The uncontrolled spread in society also meant that those in risk groups or in the higher age groups were confined to indefinite self-isolation or otherwise exposed to risk. Facebook groups and support groups emerged for parents, concerned citizens, and for those who had already had COVID-19 but experienced long-term consequences or side effects ${ }^{49}$.

As in some other countries the pandemic became politicised. It was as if a sharp dividing line cut through the population between those experiencing terror and those supporting the strategy. While an everyday terror for some, it was all accompanied by a public and media fervour of corona nationalism

\section{Corona Nationalism}

Regardless the Nordic record in deaths and ranking among the top five worst affected countries in the world, there was a conspicuous rallying behind the government and the FoHM in the Swedish media and within the general public during spring $2020^{50}$. By April, trust in the FoHM had soared to 73 percent ${ }^{51}$. Private citizens flooded the agency with flowers and a Facebook support and fan group to the state epidemiologist Tegnell emerged ${ }^{52}$. T-shirts and coffee mugs with his name were produced and sold and individuals posted new tattoos with his face or name ${ }^{53}$. Wooden sculptures and paintings were produced (Höög, 2020). Chroniclers in the media ridiculed the dissenters, who were sometimes labelled "hobby epidemologists" even though many critics were professors within the relevant medical fields. The state epidemiologist himself regularly dismissed all critics. The message from the government and the FoHM was that Sweden was the only country in the world that got this right. Neighbouring Denmark and Norway were criticised and sometimes dismissed with claims that their death rates would soon catch up ${ }^{54}$. By the end of May it resulted in a diplomatic incident where the Italian ambassador to Sweden criticised the state epidemiologist Tegnell for having made pejorative remarks about Italy and Ital-

49 The latter Facebook group had some 11,000 members by June 2020. On long-term affected see also: Vi är tusentals som aldrig tycks bli friska - hjälp oss! Available online: https://www.expressen.se/ debatt/vi-ar-tusentals-som-aldrig-tycks-bli-friska-hjalp-oss/ (accessed on 17 July 2020).

50 By July 2020, Sweden was in the top seven worst affected countries, and top five if the micro-states San Marino and Andorra are excepted, in deaths per million.

51 Coronastatus 0420. Available online: https://novus.se/coronastatus-0420-2/ (accessed on 17 July 2020).

52 Available online: https://www.washingtonpost.com/politics/2020/05/03/risk-swedens-coronavirus -strategy-blind-patriotism/

53 Available online: https://www.washingtonpost.com/politics/2020/05/03/risk-swedens-coronavirus -strategy-blind-patriotism/

${ }^{54}$ Liknande prognoser I Skandinavien. Available online: https://www.aftonbladet.se/nyheter/a/ kJOJ7B/liknande-virusprognoser-i-skandinavien The state epidemologist states in the article 6 March that one should not expect any difference in figures between the Nordic countries. 
ian healthcare ${ }^{55}$. The ambassador also pointed out that Italy's healthcare system ranked higher than Sweden's according to the WHO, and that rather than publicly reducing other countries, fighting the pandemic should be seen as a common cause. During the summer, the state epidemiologist was offered an hour on national radio as summer host, speaking directly to the nation about himself or a freely chosen topic, where he announced that he was shocked when other countries had moved into lock-down ${ }^{56}$.

Regardless of other effects of the pandemic it has boosted an inherent Swedish nationalism and self-image of being better than the rest of the world (Höög, 2020). However, it differs from conventional nationalism in the sense that it does not refer to the nation ${ }^{57}$. In this sense it is a covert or hidden nationalism, which although never referring to the nation nevertheless contains a self-image of grandiosity and xenophobic distance to "the other" which can be explained in social psychological terms. Part of the covert or hidden nationalism is that reference to the nation itself is considered inferior or base. It is part of an irrational romantic past "others" are engaged in. Swedish covert or hidden nationalism praises the Swedish superior rationality, secularism, tolerance, flexibility, and openness. In context of the pandemic, the Swedish way, or exceptionalism, is seen as an expression of this rationality. For example, unlike others, Swedes don't panic.

Everyday individual behaviour could also be interpreted along the divide between nationalist support and dissenters. Face masks, which even by 20 July were not typically used might be seen as dissenting, and the newspaper "The Local" reported that foreign residents complained about xenophobic abuse and being coughed at for wearing masks in public ${ }^{58}$.

The phenomenon follows a pattern in Sweden where branding and images have become increasingly important in political life, with a particular preoccupation with the image of Sweden abroad. In this context criticism of Sweden, especially for an international audience, may be seen as unpatriotic and disloyal to the country. A similar reaction occurred after the migrant wave in autumn 2015, when Sweden admitted considerably more refugees per capita than neighbouring countries, or other country in the E.U.

When individual researchers, whistleblowing police officers or citizens criticised a failed refugee-, migration-, or integration policy, or reported about increased crime rates, they were typically ignored or marginalised until the critique appeared in international media. When the latter happened it generated strong reactions where both the Prime Minister, Minister of Justice, and former Prime Minister and Foreign Minister attacked the citizens in the press branding their critique illoyal ${ }^{59}$. When an author of children books, Kat-

55 For example SvD 27 May 2020: Grönberg A. Italiens ambassadör riktar kritik mot Anders Tegnell. Available online: https://www.svd.se/italiens-ambassador-kritiserar-tegnell (accessed 17 July 2020)

56 Tegnell: "Som om världen blev galen". Available online: https://www.svt.se/nyheter/inrikes/tegnellsom-om-varlden-blev-galen (accessed on 17 July 2020).

57 Hence it's expression differs from what is typically described in the literature and theories of nationalism, whether modernism, constructivism (i.e. Ernest Gellner, Benedict Anderson, Eric Hobsbawm) or perennialism (i.e. Smith), as for example outlined in Smith, A. (2020).

58 Sörensen, J. S. (2020, July 17). “Skadligt att Sverige drivs som ett varumärke”. Svenska Dagbladet. Available at: https://www.svd.se/skadligt-att-sverige-drivs-som-ett-varumarke [In Swedish]

59 Sörensen, J. S. "Skadligt att Sverige drivs som ett varumärke”. Available online: https://www.svd. se/skadligt-att-sverige-drivs-som-ett-varumarke (accessed on 17 July 2020). 
erina Janouch, criticised Sweden's policy in Czech media, and when an opposition leader did so in the Wall Street Journal, the Minister of Justice claimed that such critique could be bad for Swedish business and book stores removed Janouch's books from their shelves ${ }^{60}$. For Sweden, a highly export dependent country, the very brand name of the country is important and safeguarded by the government and media. However, when individual citizens are expected or requested to adhere to an image-preserving discourse in an organic view of the state where citizens are seen as extended parts of the state organism, then the culture of free speech is threatened.

\section{Becoming unprepared}

Although the Government instructed FHM to resume testing on 31 March, and again in a televised political party debate on 7 June announced more testing, it had still not been resumed on any larger scale by mid-July ${ }^{61}$. Although the regions now had been given instruction to resume testing- and tracing the latter had no capacity to do so. On 2 June it was reported that both the Stockholm and Uppsala regions had no such capacity and that they asked patients to do this themselves, without any further follow-up or control ${ }^{62}$. This was in direct contradiction to the $\mathrm{WHO}$ recommendations to test-trace.

This reflected a more general pattern of unpreparedness, which was also the case with face masks lacking in care homes and services, or with oxygen in care homes, or respirators in hospitals.

For Sweden, the unpreparedness made the pandemic appear like what Nicholas Nassim Taleb has called a "black swan" (Nassim, 2007). A black swan is a metaphor for an event that is exceptionally rare and unlikely but which has enormous consequences, for example the asteroid impact that extinguished the life of dinosaurs. However, while pandemics are rare, they are recurring events that happen several times each century. Hence, they are not a black swan event and it is possible to be prepared for them. Sweden is a case of becoming unprepared, through a systemic neglect or incompetence with regards to crisis management. In the anatomy unpreparedness two components are of particular importance: i) becoming a government with unclear responsibility and accountability structures, between ministries, state agencies, regions, municipalities and private employers, and, ii) a public management with institutions saturated by a number of political, ideological, and economic goals outside of its core functions, and under permanent economic stress.

The first problem with unclear responsibilities has already been mentioned, but a recent example of inconsistencies is additionally instructive. The government claims it has no responsibility over care homes and that this is strictly a municipal responsibility, just as it claims it has no responsibility over health care or testing-tracing, which is a regional responsibility. Nevertheless, the government, under Socialdepartementet

60 Sörensen, J. S. "Skadligt att Sverige drivs som ett varumärke”. Available online: https://www.svd. se/skadligt-att-sverige-drivs-som-ett-varumarke (accessed on 17 July 2020).

${ }^{61}$ Folkhälsomyndigheten får i uppdrag att testa bredare. Available online: https://www.svt.se/ nyheter/inrikes/folkhalsomyndigheten-far-i-uppdrag-att-testa-bredare

62 Sveriges Radio, Ekot, 2 June 2020 “Ansvar för smittspårning läggs på patienter”. 
(Ministry of Social Affairs), had a crisis scenario exercise in early March to which it invited the agencies FoHM and Socialstyrelsen, and one point on the agenda was care homes (Sundkvist \& Simon, 2020). Still, the government chose to opt out on this issue and focus only on how to keep sustainability in the heavily pressed health care (Sundkvist \& Larsson, 2020).

Becoming unprepared has been a process ongoing since the dismantling of civil defence since the and slimming and outsourcing of government institutions since the 1990s. The weakness in crisis management has been visible before, such as during the storm 2005, the Tsunami of 2008, and with the massive security scandal with leaked and outsourcing of sensitive and confidential information from Transportstyrelsen in 2018. A case in point is the slow response to restore heat and electricity during the storm Gudrun in southern Sweden in January 2005. The storm had a heavy impact on telecommunications and electricity networks and 730,000 people were cut off from heat and electricity in the middle of the Swedish winter. It took a full 45 days before heat and electricity was fully restored to all $^{63}$. While storms and natural disasters have always affected human societies the level of preparedness has differed. Prior to the dismantling and privatization of the Swedish telecommunications agency (Televerket) in 1993, cables and telephone poles etc. were held in storage and the agency had around 45,000 employed. The standard for restoring electricity cuts during major breakdowns was one day, or two during weekends. While difficult to compare the damages and repair needs between time, the dismantling of storage and general crisis preparedness certainly plays a role in these events. With regards to hospital and IC resources a case in point is the dismantling of the civil defence and the field hospitals. In 1990 Sweden had fifty field hospitals (out of which 15 were marine). The field hospitals each had six operation halls, with each hall having sixteen respirators. This was all scrapped during the 1990s and by 2020 only one intact remained.

A more general pattern has been the slimming of the public sector with reduction or dismantling of reserves during three decades of so-called new public management reforms (NPM). While NPM hardly is a specific term, but rather an umbrella term for hundreds of different reforms across various sectors and countries they nevertheless share the same underpinning neoliberal philosophy that the market is the best information processor and that market imitating principles should be introduced across the public sector ${ }^{64}$. Hence, NPM contains a philosophy of government that contrasts with the public administration ethos that preceded it (Lundquist, 2001). Although the dismantling of reserves and preparedness must be analysed in connection with the end of the Cold War, there is also a public management and structural component at work. The introduction of market logic has in many organisations resulted in a systems stress, with lesser margins and resources for unexpected events.

63 Svt "Strömavbrott vi minns": Available online: https://www.svt.se/special/stromavbrott-vi-minns/ (accessed on 17 July 2020).

64 The term was coined by Christopher Hood in a 1991-article. For a good discussion and critical evaluation of new public management in Britain see Hood, C \& R. Dixon (2015). 


\section{Totalitarian Democracy}

The Finnish historian and cultural critic Jari Ehrnrooth has suggested that the Swedish corona strategy reveals how Sweden has become a soft version of what he calls a totalitarian democracy (Ehrnrooth, 2020). The concept of totalitarian democracy was developed by Jacob Talmon to contrast two traditions of democracy that arose with the French revolution: the liberal and the totalitarian (Talmon, 1952/1970). The tension between the two is a vital issue of our time. The liberal current not only emphasises individual rights and freedoms, but also views politics as a process of trial and error that guides the common destiny, and it recognises individual and collective endeavours outside politics. Human life takes place in and is guided through many spheres, of which the political is one. The totalitarian form, by contrast, believes in a total and exclusive truth in politics to which those who rule must guide society. This is a Messianic form of politics where the final goal of politics is reached only when these truths or beliefs reign over all spheres of life, hence it is totalitarian. Politics is simply the art of applying this philosophy to the organisation of society. It is Messianic in the sense that it postulates an order or way of life to which people must arrive and it considers politics as embracing all spheres of life. Both traditions value 'freedom', but whereas the liberal views it in terms of spontaneity and absence of coercion, the totalitarian see it realised only in the attainment of an absolute collective purpose (Talmon, 1952/1970, p. 2).

The concept helps cast light on the transition from a liberal phase to a radical phase of the French revolution during 1791-92, and to the view of democracy held by Robespierre's committee for public safety during the "reign of terror" when the republic directed violence against its own citizens, or Rousseau's concept of a "general will", which if the people does not will, "must be made to will" (Talmon, 1952/1970, p. 43). Political Messianism is mainly associated with revolutionary movements or with totalitarian dictatorships on the right or left. The Chinese cultural revolution, for example, was such a Messianic political program of cleansing directed to individuals with the "wrong will" or thought.

According to Ehrnrooth the Swedish case expresses a society where uniformity is heralded above pluralism, and where the mean is a state-led progressive doctrine with a Messianic dream of social peace (Ehrnrooth, 2020). In such a system the rallying behind the state ideology, and the expression of corona nationalism, is a common movement towards the social good, and any dissident an anti-social heretic.

The Messianic aspect of Swedish politics has also been noted by Swedish historian Svante Nordin in his recent work on Swedish modern history (Nordin, 2018). Since 1809, Nordin notes, or since the immediate aftermath of the French revolution, Swedish politics has been characterised by five major political reform waves or currents, each in which Sweden has presented itself in a self-image of rational hypermodernity and as an avant-garde in Europe and the world, and where each project also has rejected the previous as part of a decadent past ${ }^{65}$. While Nordin does not employ Talmons terminology his work can be read as a deeper historical illustration of an anti-conservative political Messianism. This view

65 These have included the constitution of 1809 , the Parliamentary reform of 1866 , the introduction of universal suffrage, the "Peoples Home" and welfare state since the 1930s, and the globalisation and multiculturalism of the past $30-40$ years. 
of politics is nevertheless anchored in a conviction that Sweden has a deep-rooted democratic tradition, but a point with the paradoxical concept of totalitarian democracy is that it is a totalitarianism that has the enthusiastic support of the people.

Moreover, unlike historical totalitarian states, the totalitarian democracy allows critique, and the system of government is a representative democracy with an elected government. But, regardless critique, even if it is science-based, there is no correction. This is well illustrated by the lack of receptivity of international research findings and studies on various aspects of COVID-19, from the existence of pre- and asymptomatic spread, the utility of using face masks, the importance of testing and tracing, the longevity of anti-bodies, how the disease affects children, to reports about potential long-term damages ${ }^{66}$. Regardless worrying reports and findings building up on these aspects, the Swedish government and FoHM remained undeterred and there was no change to the strategy or even reflection over it.

Several factors may be at play here simultaneously. While nationalism and national pride have already been discussed, there is also an element of institutional rigidity whereby an institution or organisation reacts to external critique by protecting itself with a closing of ranks. The phenomenon of cognitive dissonance, as described and theorised by Leon Festinger in the 1950's, may be especially relevant, as it contains a range of advanced psychological mechanisms for denial and for rejecting any evidence in contradiction with established beliefs or that generates emotional stress (Festinger, 1957). Cognitive dissonance must be assumed to play a considerable role in Sweden, at least with regards to popular behaviour. Another factor could be institutional capture by an individual or group of individuals with particular psychological characteristics. However, the concept of totalitarian democracy provides a lens for a deeper understanding of political culture. The reason there is no greater dissenting movement is a collectivist mentality in which individual life is subordinate to the collective.

\section{Conclusion}

The Swedish response to the corona pandemic during spring-summer 2020 came to stand out as an extreme international outlier. The relaxed approach remained undeterred regardless death rates rising and placing Sweden among the seven worst affected countries in the world, or in face of international critical reactions or even new research findings that would give cause for concern. For many Swedes, unable to protect themselves, in care homes, elderly utilising home service, parents or school children in risk groups, or other people in risk groups during the spread of COVID-19 in spring 2020, the condition increasingly resembled tyranny or terror. While the pandemic, just as in many other countries, divided the population and created new strictures, it also revealed a remarkable rallying behind the government, at least initially. This included most of the national media. Dissenters were marginalised, silenced, or ridiculed. Several factors may be required to explain

66 While there were case studies and reports about some of these during spring 2020, for example reports on the asymptomatic spread and the utility of face masks, or about long-term effects and chronic damages, there where by mid-July 2020 quite a number of worrying reports and studies on all of the mentioned aspects. 
this, including cognitive dissonance, gaslighting, and national pride, but a deeper political culture has been revealed, in which Sweden can be understood in terms of Messianic radicalism and totalitarian democracy. The pandemic has also brought to the fore a range of pre-existing dysfunctional aspects of the state, on administrative as well as legal and constitutional level. The manipulation of or withholding of information, both between branches of the public sector and government, and between the public sector and population, secrecy, and cover ups, have revealed deep-rooted democratic and transparency problems in the state. The lack of equipment, problems in organisation, and ethically questionable practices, have unmasked deep fractures in the welfare system and in the whole Swedish model. The exposure of risk groups, treatment of elderly, and institutional incapacity to receive and adapt to new information, are likely to be factors with deep and long-term ramifications across Swedish society and in public debate. On an international level, Sweden's utopian dream of being a model society of general welfare, of solidarity and a humanitarian superpower, effectively suffocated in the pandemic of COVID-19. 
Јенс Стилхоф Соренсен ${ }^{1}$

Универзитет у Гетеборгу,

Факултет глобалних студија,

Студије за мир и развој / Међународни односи

Гетеборг (Шведска)

\section{ТЕРОР У УТОПИЈИ: КРИЗНО (ЛОШЕ) РУКОВОЪЕЊЕ ТОКОМ COVID-19 ПАНДЕМИЈЕ У ШВЕДСКОЈ}

„Огледалце, огледалце моје, најхуманија држава на свету која је?”

(Превоg In Extenso)

Сажетак: Овај текст пружа рани осврт ка документовању шведске стратегије током COVID-19 пандемије и критички истражује реакцију државе на кризу током првих шест месеци 2020. године. Шведска се на међународном нивоу издвојила неинтервентним приступом који је привукао пуно пажње. Школе су остале отворене, није уведено ванредно стање, нису препоручене маске за лице, чак ни у домовима за старе, а тестирање-праћење-изолација је било врло ограничено. Иако је шведска стопа смртности на милион грађана била међу седам највиших на свету током тог периода, стратегија није мењана. Овај текст користи концепте за анализу и разумевање овог специфичног приступа, и културе безбедности и политичке културе на коју се приступ ослања. Рад открива дубље системске недостатке и слом државних функција праћених тајношћу и заташкавањем, као и тоталитарни елемент у политичкој култури.

Кључне речи: Шведска, COVID-19, пандемија, стратегија, култура, тоталитарна демократија

\section{Увод}

Шведска је често приказивана као интернационални узор солидарности, друштвеног благостања и хуманитаризма². У Сједињеним Америчким Државама су је, на пример, демократе у време Кенедијеве администрације, ако не и раније,

\footnotetext{
1 jcs@stilhoff.se

2 Желео бих да изразим посебну захвалност групи научника Forum Vetcov-19 у Шведској на континуираној дискусији о низу питања на ту тему. Доступно на мрежи: http://vetcov19.se/ (приступљено 17. јула 2020).
} 
наводиле као узор, али и као конформистички социјални затвор ${ }^{3}$. Шведска спољна политика је и сама имала за циљ промоцију Шведске као узора, бар од времена Улофа Палмеа, социјалдемократског премијера убијеног у атентату 1986. године. Током хладног рата, њена политика неутралности пратила је визију „трећег пута” у глобалној политици. Као држави високозависној од извоза, овакав утопијски имиџ Шведске као узора служио је економској сврси а наставио је да буде негован и након хладног рата. Шведска је, било кроз страну помоћ или као најлибералнија европска избегличка политика, пројектовала себе као хуманитарну суперсилу и подстицала феминистичку спољну политику са нормама егалитаризма с циљем њиховог ширења по свету. Током прве половине 2020. године и COVID-19 пандемије, такав (ауто)имиџ шведске изузетности бива тешко погођен.

Одговор на кризу и управљање њом, које је Шведска усвојила током COVID-19 пандемије, у пролеће 2020. године се издвојило као значајно другачије од било које суседне земље, а у том смислу и од Европе и света. Иако се одговор на кризу глобално разликовао, посебно између и унутар европских и азијских региона, шведски пут је био довољно јединствен да привуче значајну пажњу међународних медија, те заслужује ближе испитивање. Анализа ширих друштвених ефеката и последица у време писања овог извештаја (средина јула 2020) може се чинити преурањеном и темељна процена би требало да сачека док се први и могуће други талас пандемије не заврши. Ипак, и даље је могуће и важно анализирати одговор на кризу током првих шест месеци и талас пандемије, обухватајући период од открића избијања болести у јануару до јула 2020. године. Овај текст намерава да то учини критичким испитивањем стратегије и динамике између шведске владе и релевантних власти, медицинских стручњака и шведске јавности током овог почетног периода. Циљ је разумевање шведског друштва и безбедносне културе ближим освртом на начин функционисања током кризе, а фокус ће бити на анализи комуникације и прописа предложених или непредложених од стране власти, као и њихових последица и пријема код становништва. Пишући током средине наведеног периода (рано лето 2020), за већину догађаја и мера било је мало или нимало секундарне литературе на коју се могло ослонити. Извори се састоје од обимног материјала укључујући „меке изворе”, као што су изјаве на конференцијама за штампу, интервјуи у медијима и новински извештаји, али и извештаји владиних агенција. Што се тиче „меких извора” попут вести, реч је о реномираним и етаблираним медијима, а све информације су двоструко проверене или даље праћене када се то чинило релевантним, као што је то, на пример, случај са неким изјавама узбуњивача јавности. Како је овај вирус нов, врло је мало академских књига или чланака који би у овој фази могли да пруже значајан допринос. Литература која се односи на друге пандемије је информативна до одређене мере, али, као што су други утврдили, овај конкретни вирус има неке нове аспекте и још увек није у потпуности схваћен, укључујући појаве стварања кластера. У годинама које долазе, без сумње ће се знати много више. Што се тиче питања вирусологије и медицине, у медицинским часописима или здравственим

\footnotetext{
${ }^{3}$ Есеј Сузан Зонтаг „Писмо из Шведске”, објављен у часопису Рампартс, јул 1969. године (стр. 23-38), представио је Шведску у овом другом, негативном имиџу, баш као што су то чинили неки говори Доналда Трампа. Супротно томе, за неке демократе и социјалне либерале Шведска се понекад користила као модел.
} 
агенцијама свакодневно се извештавало о новим налазима, а нова истраживања су се брзо појављивала. Њихов карактер је варирао од рецензираних или нерецензираних радова у часописима, од двоструко слепих студија до метаанализа, бихевиористичких или кохортних студија, па све до извештаја здравствених агенција. Брзина нових налаза који су најрелевантнији за овде анализирану политику мера посебно је повезана са питањем пресимптоматског и асимптоматског ширења, питањем аеросолног ширења, питањем ефективности маски за лице, питањем деце и болести, а тиме и улоге школа у ширењу вируса, и извештаја о медицински дугорочним ефектима вируса. Као особа изван лекарске професије, аутор је континуирано дискутовао налазе и нове детаље у оквиру научног форума (Vetcov-19) који се састоји од неколико десетина (углавном) шведских лекара, укључујући вирусологе и епидемологе. Иако очигледно не представљају главно интересовање, вирусологија и медицински аспекти били су важна позадина, те је ова референтна група била од велике користи.

Постоји опсежна литература о системима јавног здравља и њиховим управљањем, различитим реакцијама на пандемије, али детаљније бављење њима превазилази оквире овог текста. Поређења са остатком света су у извесној мери могућа, али да би се то у потпуности извело треба размотрити многе варијабле (густина насељености, старосна структура, културни обрасци понашања попут претходне навике ношења маски, вероватно климу и неколико других фактора.) Будуће упоредне студије, укључујући дијахронијска поређења или поређења међу земљама, биће важне за дубље разумевање шведског случаја. Фокус овде је пре на ситуацију у Шведској, како се развијала и како је доживљена, изборима које су Влада и Агенција за јавно здравље рано начиниле, а који су и даље присутни. Начињена су, где је то прикладно, нека упоредна запажања са другим нордијским земљама, за које би се могло очекивати да имају сличне нивое инфекције/смртности да су предузимале сличне мере. У описивању и анализи текућих догађаја уводе се и објашњавају теоријски концепти када се појаве као релевантни, попут „нових реформи јавног управљања“ и њиховог односа према спремности за кризу у шведском случају, а са освртом на нека критичка запажања о шведском национализму и особеностима шведске државне и политичке културе. Неки концепти су представљени пре као педагошко критички него теоријски конструкти.

\section{Шведска: сопствени пут}

Следећи званично декларацију Светске здравствене организације (СЗО) од 11. марта 2020. године о пандемији COVID-19, већина европских земаља је током марта увела различите нивое ограничавања кретања и затварања школа ${ }^{4}$. Италија је то започела већ 9. марта, а школе затворила 5. марта. Све остале нордијске земље брзо су кренуле са рестрикцијама и затвориле школе, барове и ресторане, као и границе за све који нису грађани или становници, почев од Данске 14. марта, Норвешке 16. марта и Финске 18. марта 5 . Такође су покренуле праћење контаката и изолацију случајева.

\footnotetext{
${ }^{4}$ На пример: Италија 9. 3, Шпанија 14. 3, Аустрија 16. 3, Француска 17. 3.

${ }^{5}$ Коронавирус (COVID-19) у Нордима - статистика и чињенице. Доступно на интернету: https://www.statista.com/topics/6123/coronavirus-COVID-19-in-the-nordics/\#dossierSummary_ chapter6 (приступљено 29. јуна 2020).
} 
Шведска је, као изузетак, само привремено затворила гимназије (које су поново отворене 16. јуна) и прешла на онлајн универзитетску наставу, док су све школе остале отворене. У почетку су Британија и Шведска следиле исти пут са циљем ублажавања (или ка „имунитету стада”), али је Британија напустила ову стратегију 16. марта тврдећи да је заснована на погрешним проценама и да ће довести до превише мртвих пре него што се постигне циљ ${ }^{6}$. Шведска је наставила са сопственом стратегијом отворености. Генерално, није било ограничења путовања или кретања, није било тестирања и праћења, препорука за маске за лице чак ни у болницама или домовима за негу, нити других сличних мера које су почеле да се примењују широм Европе. Уведено је ограничење окупљања, најпре на 500 (12. марта), а затим на 50 људи (29. марта) ${ }^{7}$. Ресторани, барови, продавнице, клубови су остали отворени, уз неке изузетке. ФоХМ је препоручио прање руку и држање социјалне дистанце, као и останак кући и изостајање са посла или из школе у случају симптома попут грознице. Чини се да је стратегија, о којој се даље говори, иако нејасна и понекад званично негирана, циљала на имунитет стада омогућавањем спорог ширења међу популацијом, истовремено штитећи ризичне групе и одржавајући темпо ширења на нивоу који неће преоптеретити здравствени систем. Као што је даље образложено, ово никада није било јасно речено, што је довело до веће конфузије, па се стратегија стога мора интерпретирати и изводити из предузетих или непредузетих радњи.

У Европи је једино Белорусија изабрала сличан пут. Ипак, иако су у Белорусији школе остале отворене, није било обавезе, те су родитељи који су били у могућности могли децу да држе код куће. Централне и регионалне власти у Белорусији су такође давале јаче препоруке по питању заштитних мера у јавним просторима и у школама од краја априла. У Шведској су, с друге стране, чак и родитељи који су припадали ризичним групама и пацијетни са потрвђеном COVID-19 инфекцијом морали да шаљу децу у школу ризикујући казну уколико то не би учинили.

\footnotetext{
6 Термин „имунитет стада” (лаички израз за „ублажавање”) није званично коришћен и често је негиран, али, као што ће бити образложено у наставку, та се стратегија може извести из предузетих или непредузетих радњи. Државни епидемиолог Тегнел изјавио је 17. марта да они (ФоХМ) нису користили тај израз, али да су посматрали Британију, те да је нешто попут имунитета стада стање које Шведска треба да достигне: P. J. Larsson Anders Tegnell hillar Brittisk tanke kring flockimmunitet: „Dit vi behover komma”. Доступно на мрежи: https://vvv. aftonbladet.se/niheter/a/6j7vaO/anders-tegnell-hillar-brittisk-tanke-kring-flockimmunitet-dit-vibeh (приступљено 17. марта 2020); у интервјуу за Nature 21. априла изјавио је да „свака земља мора да постигне имунитет стада”: Paterlini, M. „Затварање граница је смешно”, епидемиолог који стоји иза шведске контроверзне стратегије коронавируса. Доступно на мрежи: https:// vvv.nature.com/articles/d41586-020-01098-k (приступљено 14. јула 2020). За стратегију у северноевропским земљама видети: Caracciolo, B (2020) „Како је стратегија ублажавања довела у искушење северну Европу, а убедила само Шведску", Medijum, 17. јул 2020. Доступно на мрежи: https://medium.com/@barbara.caracciolo2020/how-the-mitigation-strategy-temptednorthern-europe-and-convinced-only-sweden-f6fb9197d49a (приступљено 17. 07. 2020).

${ }^{7}$ Владина одлука 11. марта (у примени од 12. марта). Доступно на мрежи: https://www. regeringen.se/artiklar/2020/03/forordning-om-forbud-mot-att-halla-allmanna-sammankomsteroch-offentliga-tillstallningar/

И одлука од 27. марта (у примени од 29. марта). Доступно на мрежи: https://www.regeringen. se/artiklar/2020/03/forbud-mot-allmanna-sammankomster-eller-offentliga-tillstallningar-medfler-an-50-deltagare/
} 
Док су шведски експерти упозоравали на пандемију још у јануару, Влада је то одбацила а медији често исмевали ${ }^{8}$. Иако је било супротстављања и критике у медицинским и научним круговима, стратегија је, чини се, имала општу подршку у популацији, што ће бити анализирано у посебној секцији о национализму ниже у тексту.

Осим Шведских демократа (национално-конзервативне странке), који су континуирано постављали критичка питања у Парламенту, већина политичких партија дала је пасивни пристанак све до отприлике маја, када су почеле са изношењем критика јер је стопа смртности порасла на међу највише у Европи. Шведска се до 30. априла сврстала међу првих десет на свету са највише COVID-19 смртних случајева на милион становника, са 244, или око седам пута већом стопом од суседне Финске и Норвешке (ourworldindata.org приступљено ). Почетком јуна ниво смртних случајева у Шведској је удвостручен у односу на суседни регион свих осталих нордијских земаља, свих балтичких земаља, Пољске и Калињинграда заједно. Шведска је до 8. јула достигла ниво од 538 смртних случајева на милион становника, превазилазећи за готово четрдесет посто, на пример, САД, које су имале 394 (ourworldindata. org). У међувремену, супротно неким претпоставкама, економија је била подједнако лоше погођена као и у земљама које су увеле ограничење кретања и окупљања9. Заправо, шведска стопа незапослености остала је и даље виша од просека ЕУ, и виша него у другим нордијским земљама или Немачкој.

Када су нордијске земље у јуну отвориле међусобне границе, Шведска је остала искључена. Финска, Данска и Норвешка, али и УК су задржали ограничења за путнике из Шведске, који би морали да проведу време у карантину. Чешко министарство здравља је Шведској доделило статус зоне највећег ризика у ЕУ (Pirodsky, 2020). Шведска је постала масовно жариште болести и епицентар у северној Европи.

Како је време одмицало, а број умрлих растао, шведски пут се истицао као још необичнији. Маске за лице нису биле предвиђене ни у болницама, ни у домовима за негу оних који раде са сумњивим или потврђеним COVID-19 случајевима (Schneider, 2020). Тек је 25. јуна 2020. године и након више од 5.000 смртних случајева, шведска ФоХМ препоручила да се маске за лице или заштита користе у болницама и домовима за негу, али чак и тада само у вези са потврђеним или сумњивим случајевима ${ }^{10}$. Другим речима, шведској Агенцији за јавно здравље било је потребно шест месеци, усред пандемије, да свим здравственим радницима у контакту са потврђеним COVID-19 пацијентима препоручи маску и штитник за лице ${ }^{11}$. Што се пак тиче јавности и свих осталих здравствених радника који немају контакта ca COVID-19,

${ }^{8}$ На пример, Бјорн Олсен, професор инфективних болести на Универзитету Упсала, упозорио је на долазећу пандемију у јануару, а 14. априла, 22 научника из разних дисциплина, од епидемиологије и вирусологије до математике и биостатистике, упозорило је и позвало на промену шведске стратегије. Били су увелико одбачени и у медијима их је дискредитовало и шведско Агенција за јавно здравље (Folkhälsomyndigheten - FoHM/ФоXM).

${ }^{9}$ Svensk coronastrategi ingen ekonomisk vinnare: https://www.sydsvenskan.se/2020-06-10/svenskcoronastrategi-ingen-ekonomisk-vinnare (приступљено 10. јуна 2020).

10 ФоХМ конференција за штампу 25. јун 2020 (Svt Nyheter).

11 Треба напоменути да су многе болнице свеједно користиле маске за лице за персонал у контакту са инфициранима, што је ипак била локална одлука и значајно је варирала између региона и клиника. 
шведске власти и државни епидемиолог и даље су инсистирали на обесхрабривању употребе маски за лице, иако су научници широм света упозоравали на то да се вирус преноси ваздухом, те да маске за лице пружају заштиту ${ }^{12}$.

\section{Совјетизација шведске државе}

Шта је била шведска стратегија и да ли је уопште постојала? Када се анализира шведска стратегија, важно је прво уочити особеност у погледу дужности и одговорности у шведском јавном сектору. Шведска влада, премијер и министар здравља били су упадљиво одсутни са јавне сцене током већег дела пролећа 2020. године. Премијер није месецима давао интервјуе, давао је само неке унапред снимљене поруке, а у парламенту није формирана ниједна кризна група. Одговорност за управљање кризом је на нејасан начин подељена између Агенције за јавно здравље (ФоХM) са њеним генералним директором (Johan Carlsson) и државним епидемиологом (Anders Tegnell), као и између региона и општина одговорних за здравствену заштиту, бригу о старима и школама, редом. Укључене су и друге агенције, попут Националног одбора за здравство и социјалну заштиту (Socialstirelsen), који надгледа медицинску професију, и Агенције за цивилне случајеве МСБ. Прецизна инстанца одговорности за проблем је остала нејасна. Влада (премијер и министар здравља) је тврдила да нема надлежност за пандемију или медицинска питања, па је упућивала на ФоХМ и државног епидемиолога. Што се тиче одговорности за смртне случајеве у здравству и нези старих, и ФоХМ и Влада су упућивале на регионе, а понекад и на општине. Двадесет и четири регионалне владе биле су одговорне за опрему, приправност за кризу, као и за здравство. Општине су биле одговорне за домове за негу, као и приватне компаније које су их водиле. Појединачне болнице и домови су заузврат упућивали на ФоХМ у вези са препорукама и процедурама које треба следити, маскама за лице и осталом опремом. То је затворило круг у коме је ФоХМ устврдила да није одговорна за клинике или домове за негу, док су ови упућивали на ФоХМ у погледу процедура, правила или прописа, којих се јесу или нису придржавали.

Ситуација са врдајућом структуром одговорности додатно је искомпликована праксом тајности и недостатком транспарентности у шведској држави. На формалном нивоу, шведски устав и закони који регулишу администрацију гарантују транспарентност јавних агенција, општина и региона, тако да новинари или

12 У интервјуу за ДН, 27. јуна, државни епидемиолог Тегнел говорио је против јавне употребе маски за лице. Доступно на мрежи: https://vvv.dn.se/niheter/sverige/anders-tegnell-landernasoppnande-ett-gigantiskt-ekperiment/, док су истраживања доказала њихову ефективност, на пример: Face masks for the public during the COVID-19 crisis. Доступно на мрежи: https://vvv. bmj.com/content/369/bmj.m1435 (приступљено 9. априла 2020) и датотека: /// C: / Users / Jens / AppData / Local / Microsoft / Vindovs / INetCache /IE/2VKZNNGF/PIIS0140673620311429. pdf и датотека: /// C: /Users/Jens/AppData/Local/Microsoft/Vindovs/INetCache/IE/ J3KJVM8V/dp13319.pdf. Почетком јула, 239 научника из 32 земље написало је писмо С3О упозоравајући да се вирус преноси ваздухом: Jee C. A group of 239 scientists says there's grooving evidence COVID-19 is airborne. Доступно на мрежи: https://vvv.technologireviev. com/2020/07/07/1004841/a-group-of-239-scientists-sai-theres-groving-evidence-COVID-19-isairborne/ (приступљено 7. јула 2020). 
индивидуални грађани могу добити приступ документима, укључујући и интерну преписку, осим ако то није посебно означено као поверљиво одлуком која се изричито позива на неки правни параграф ${ }^{13}$.

Међутим, модели и претпоставке коришћене од стране ФоХМ нису били јавни, па их истраживачка заједница или јавност није могла анализирати. Уместо тога, морали су да се ослоне на информације представљене на дневним конференцијама за штампу које су почеле да се одржавају у 14 сати. Успостављен је дневни ритуал, са ФоХМ-ом и државним епидемиологом који су давали изјаве, а иако би их пратила питања новинара, ниједан од присутних (углавном шведских) новинара не би постављао критичка питања. Мало је њих доводило у питање недостатак транспарентности или захтевало увид у моделе или претпоставке иза „стратегије”. ФоХМ није до 24. априла објавио сопствени кодекс (а исправио га је 26. априла).

Тајност и недостатак транспарентности били су део општијег обрасца. Региони нису делили информације које су имали о ширењу болести у општинама у оквиру региона. Општина Стафансторп је на управном суду од региона Сконе тражила информације за општину (и добила случај). Основне и средње школе често су одбијале да дају било какве информације о томе да ли је ученику или родитељу дијагностикован COVID-19. Наставници су такође често били неинформисани. У Сормланду, близу Стокхолма, неке општине су држале у тајности број умрлих у домовима за негу, а на регионалном нивоу виши званичници су држали у тајности и планирали да прикрију стопу смртности за регион ${ }^{14}$. Упсала, четврти по величини шведски град, заташкао је или одбио да стави на увид јавности број инфицираних у домовима за негу (Sveriges Radio, 16. јуни). Такође у Упсали, руководство универзитетске болнице (Akademiska Sjukhuset) је држало у тајности чињеницу да ce COVID-19 шири у породилишту ${ }^{15}$.

Поверење у државну стратегију и препоруке ФоХМ-а нису делили сви. Највећи шведски синдикат Kommunal, који организује пола милиона радника на општинском и регионалном нивоу, сумњао је у Владу и ФоХМ: тврдње да приликом лечења COVID-19 пацијената нису потребне маске за лице или заштитна опрема, а након ширења COVID-19 у дому за негу Серафен у Стокхолму покренуо је блокаду или обуставу рада ${ }^{16}$. Kommunal је водио парницу позивајући се на шведски закон о радном окружењу и заштиту својих радника, а не старијих који живе у дому за негу. Случај је поднет шведској Управи за радно окружење, која је пресудила у корист

13 То значи да је основно стање јавни приступ и транспарентност, те да одређени документ да би постао поверљив мора бити означен посебним мотивом и правном референцом која се, на пример, позива на акт о поверљивости или индивидуалној приватности.

${ }^{14}$ Разни чланци у Eskilstinakuriren: se 2/5-20 "Professorn starkt kritisk till kommunernas mörkläggning”. Доступно на мрежи: https://ekuriren.se/artikel/wjo397yj and 8/6-20 Efter mörkläggningen - kommunerna får bakläxa. Доступно на мрежи: https:/ekuriren.se/bli-prenumerant/artikel/ 8 rxxg38r

15 Förlossningen vid Akademiska Sjukhuset drabbades av smittspridning ledningen la locket på. Доступно на мрежи: https://www.svt.se/nyheter/lokalt/uppsala/forlossningen-vid-akademiskasjukhuset-drabbades-av-smittspridning-ledningen-la-locket pa?fbclid=IwAR0OGjOTZ7iyhclzv BJnB6NalJdrEDLhfXE9gJtFgTcx0eJJlTmadL2pVQw (приступљено 17. маја 2020).

${ }^{16}$ Kommunal: "Vi fortsätter lägga skyddsstop". Доступно на мрежи: https://www.svt.se/nyheter/ lokalt/stockholm/kommunal-vi-fortsatter-lagga-skyddsstopp (14. априла 2020). 
Kommunal-a ${ }^{17}$. То је заузврат довело до тога да Шведске општине и региони (Sveriges Kommuner och Regioner), политичка интересна организација за општине и регије са нејасним статусом, поведе кампању лобирања против шведске Управе за радно окружење (SWEA/CBEA). У недостатку маски за лице и основне опреме у регионима, плашили су се да ће одлука постати преседан, те су хтели да СВЕА преиначи одлуку, што се и догодило ${ }^{18}$. Чињеница да су региони и општине на политичком нивоу вршили притисак на власти да одустану од препоруке заштитне опреме приликом рада са пацијентима ca COVID-19 у домовима за негу ће, евентуално, од стране неких уредништава, бити тумачена као претња поверењу у институције у Шведској (Pihl, 2020).

Шведска је до 18. јуна забележила раст нових случајева, који је био петнаест пута већи од шест суседних нордијских и балтичких земаља заједно ${ }^{19}$. Као реакција на то што су медији почели да извештавају о недостатку компетентности и спремности за кризу, упркос супротним тврдњама Владе, ФоХМ је већ од 17. марта па надаље почела да све записнике са састанака са регионалним медицинским службеницима (smittskiddslakare) чува као тајне ${ }^{20}$. Ипак, ово је у основи представљало кршење транспарентности шведских јавних агенција, које је иначе регулисано Уставом.

Образац тајности, заташкавања и манипулације информацијама на државном, регионалном и општинском нивоу је почео да бива видљив.

Након што је СВЕИ-ино умањивање улоге маски за лице процурило у медије, CBEA је започела заташкавање брисањем електронских мејлова које су новинари тражили ${ }^{21}$. Исту праксу користио је регион Сормланд како би сакрио незгодне информације од новинара ${ }^{22}$.

Иако представља кршење шведског закона, ова пракса постала је релативно честа (Valsten, 2020). Заправо, ова пракса је толико развијена да можемо говорити о појави „менаџмента из сенке” у Шведској, а мало је разлога за страх од било каквих законских санкција, јер шведски правни систем обично не санкционише носиоце моћи (Sorensen \& Olsson, 2020). Ово, у крајњој линији, подрива шведски устав

17 Ewald, H. Kommunal får rätt - munskydd och visir ett måste. Доступно на мрежи: https://www. dn.se/sthlm/kommunal-far-ratt-munskydd-och-visir-ett-maste/ (приступљено 8. априла 2020).

${ }^{18}$ SVT avslöjar: kommunernas intresseorganisation fick myndigheter att tona ned munskyddskrav. Доступно на мрежи: https://www.svt.se/nyheter/inrikes/svt-avslojar-kommunernas-intresse organisation-fick-myndigheter-att-tona-ned-munskyddskrav (приступљено 29. јуна 2020).

19 Шведска је имала 1.239 нових случајева, Данска 44, Норвешка 20, Финска 5, Естонија 2, Летонија 6 и Литванија 2 (видети Yaneer Bar-Yam, endcoronavirus.org 18/6).

${ }^{20}$ Minskad insyn hos FHM- mötesanteckningar hålls hemliga. Доступно на мрежи: https://www. svt.se/nyheter/inrikes/minskad-insyn-hos-fhm-motesanteckningar-halls-hemliga (приступљено 1. јуна 2020).

${ }^{21}$ Myndigheten ville slippa "svår debatt" om munskydden - framgår av mejl som raderats. Дocтупно на мрежи: https://www.svt.se/nyheter/inrikes/kritiserade-myndigheten-ville-slippa-svardebatt-om-munskydden-framgar-av-mejl-som-raderats (приступљено 30. маја 2020) и Efter granskningen: Personal på Arbetsmiljöverket uppmanas radera mejl. Доступно на мрежи: https:// www.svt.se/nyheter/efter-granskningen-personal-pa-arbetsmiljoverket-uppmanas-radera-mejl (приступљено 8. јуна 2020).

${ }^{22}$ Regiondirektörens mejl kastade - kan vara tjänstefel. Доступно на мрежи: https://ekuriren.se/ bli-prenumerant/artikel/elwdw11r 
(посебно Offentlighetsprincipen, „Принцип отворености” и Regeringsformen, „Инструмент Владе") и централну инфраструктуру демократске државе.

Тако је пандемија почела да открива системски проблем унутар шведске државе, образац тајности, прикривања и избегавања одговорности, или оно што бисмо политичком аналогијом могли назвати „совјетизацијом”.

\section{Хипотеза стратегије}

Како је већ поменуто и како ће даље бити дискутовано у следећем пасусу, шведска влада или релевантне власти нису имале јасну комуникацијску стратегију, а модели и претпоставке ФоХМ нису били доступне јавности. Уместо тога, бројне изврдавајуће и контрадикторне изјаве отежале су утврђивање тога шта је заправо циљ. Међутим, стратегија се - ако се може тако назвати - може извести из предузетих или непредузетих радњи. Понекад би јавни службеници то потврдили, иако би други званичници то касније негирали или давали опречне информације.

Овде износим хипотезу да је стратегија била постизање имунитета стада, што се темељи на следећим претпоставкама ФоХМ-а:

1. COVID-19 je „попут грипа” и понаша се попут грипа (ова претпоставка је била нетачна, јер се не понаша попут грипа. На пример, ширење није једнако већ прати образац кластера, а старосна дистрибуција и морталитет су различити, у зависности од годишта).

2. Већина људи ће га на крају добити, тако да нема сврхе покушавати да се заустави, што је јавно изјавио Јохан Гисецке, бивши државни епидемиолог и саветник ФоХМ-а, као и службеник за контролу болести Норботен ${ }^{23}$. Штавише, за 98\% инфицираних било би безазлено и чак неприметно ${ }^{24}$.

3. Стога је било најбоље покушати са мерама ублажавања и заштитити систем од преоптерећења. И заштитити ризичне групе, посебно домове за негу. Треба, међутим, напоменути да су Андерс Тегнел и ФоХМ знали за недостатак капацитета у домовима за старе, уз проблеме који се односе на регулативу, особље, организацију, и то су чак јавно изјавили ${ }^{25}$.

Тако, док је италијански модел требало да заустави инфекцију, Шведска је (као Велика Британија до 16. марта) хтела да се зараза шири, али на посебне групе и контролисаним темпом. Ширење је, ипак, био циљ. Ако се људи инфицирају, постају

${ }^{23}$ Ово је често и најексплицитније износио бивши државни епидемиолог Јохан Гисецке, који је служио као саветник ФоХМ-а и редовно давао интервјуе објашњавајући „нашу стратегију” (ФоХМ:с), на пример на шведској државној телевизији: Svt Morgonsoffan 28. маја 2020. Доступно на мрежи : https://vvv.svt.se/niheter/inrikes/giesecke-det-ar-inte-sakert-att-ett-vaccinkommer-vara-effektivt; на конференцији за штампу 31. марта службеник за контролу болести у регији Норботен изричито је изјавио да је циљ (барем за регион) „имунитет стада”.

${ }^{24}$ Гисецке у интервјуу на државној телевизији 6. маја 2020: Giesecke: Det är inte säkert att ett vaccin kommer vara effektivi. Доступно на мрежи: https://www.svt.se/nyheter/inrikes/gieseckedet-ar-inte-sakert-att-ett-vaccin-kommer-vara-effektivt (приступљено 17. јула 2020).

25 Генерални директор Јохан Карлсон је 7. јула изнео тврдњу да је недостатак капацитета у домовима за негу у Шведској добро познат већ годинама и да је утврђен у три узастопна владина испитивања: Carlsson till motattack mot Akesson. Доступно на мрежи: https://vvv. aftonbladet.se/niheter/a/4kMzlk/carlson-till-motattack-mot-akesson (приступљено 17. јула 2020). 
имуни (ово се испоставило неизвесним, а претпоставка смелом и опасном) те не могу да заразе друге. То је суштина имунитета стада постигнутог без вакцинације, а идеја је раширена у северној Европи и темељена на лекцијама из епизоде шпанског грипа (Caracciolo, 2020). Чинило се да је циљ био идеалан биланс улазно-излазних бројева у болницама.

Ослањајући се на другу претпоставку, да деца нису посебно подложна болести и да не инфицирају друге (опет делимично нетачно), школе треба држати отворенима. На тај начин се школе могу користити за равномерно ширење болести кроз друштво, а ако ширење треба успорити, „славина” се може заврнути затварањем. Дакле, школе су регулатор за пренос болести, а ка имунитету стада.

Без обзира да ли је ово била намеравана стратегија или не, шведска држава је то примењивала. У сваком случају, претпоставка да је циљ био имунитет стада остаје, јер у супротном ниједна акција нема смисла: а) отворене школе, б) инсистирање на томе да се не препоручују маске за лице, па чак у одређеној мери и спречавање њиховог коришћења уз тврдњу да је контрапродуктивно (људи ће постати немарнији ако верују у маске, и слично) и да би чак могло да повећа ширење, све без емпиријске подлоге или доказа и, на крају, до јуна, у директној супоротности са евиденцијом ${ }^{26}$.

До априла, нејасноће око тога на шта циљају шведска влада и власти навеле су епидемиолошкињу Карину Кинг да сугерише да се осећа слуђеном (gaslighted) од стране надлежних. Уводник Ивара Арпија у главном дневном листу Svenska Dagbladet бави се том темом 15. маја (Arpi, 2020). Термин gaslighting потиче из чувеног филма „Плинско светло” (Gaslight, 1944) у коме глуми Ингрид Бергман. Филм се ослања на срачунату стратегију супруга да убеди своју жену у њено сопствено лудило.

\section{Слуђивање}

Чини се да су до априла шведске власти водиле игру слуђивања становништва. Разумна питања су одбачена, критички истраживачи или лекари приказани су као јеретици, а константно су даване контрадикторне изјаве.

Најосновнији аспекти тога су:

а) нејасна инстанца одговорности;

б) нејасноће и контрадикторне изјаве о томе шта је била стратегија;

ц) обмањујуће изјаве о заштитној опреми, попут маски за лице;

г) обмањујуће изјаве о пресимптоматској и асимптоматској инфекцији;

е) убеђивање становништва да је остатак света предузео погрешне кораке и да ће на крају достићи исте стопе смртности као Шведска или, алтернативно, да поређења нису смислена;

ф) циљање да се дискредитује свака критика или научни доказ који се не уклапа у изјаве ФоХМ-а.

26 Чак је и 14. јула, када је већина других земаља увела маске за лице, а британски премијер одржао говор о потреби ношења маски за лице у јавним просторима у Великој Британији, шведски ФоХМ тврдила је супротно. Карин Тегмарк Вигсел, портпаролка ФоХМ-а, тврдила је да је употреба маски за лице у другим земљама повећала ширење болести, што сугерише да су друге земље погрешиле и да су, у ствари, имале контрапродуктивне препоруке: Utokad karantan kan bli aktuell - och kanske minskidd . Доступно на мрежи: https://vvv.aftonbladet.se/ niheter/a/kJ24jv/utokad-karantan-kan-bli-aktuell--och-kanske-munskidd-i-vissa-fall 
Неке од ових тачака су већ поменуте, попут двосмислености по питању тога ко је одговоран и обмањујуће изјаве о заштитној опреми. Двосмислене изјаве током пролећа и лета 2020. године давали су у континуитету како Влада (премијер, министар здравља), тако и главни оператор ФоХМ-а. На пример: државни епидемиолог Тегнел је 13. марта прокламовао да нова стратегија није вршење тестирања или тражење контаката, јер то нема сврхе и није важно знати колико је људи заражено (Karlsson, 2020). То се десило у време када је Норвешка прешла на ограничење кретања и окупљања. То је, међутим, доведено у питање у јуну, када је дошло до знатног ширења инфекције, те је 26. јуна Влада наложила ФХМ-у да настави тестирање 27. Влада је тврдила да је Шведска ушла у „касну фазу пандемије”28. Међутим, у време када је ова изјава дата, број активно инфицираних се повећавао, са 27.879 на дан 2. јуна, на 32.731 на дан 8. јуна, што је пораст од 17,5\%. Тврдња да се ради о смањењу и фази касне пандемије једноставно није имала смисла. Такође није имало смисла тврдити да је тестирање било бескорисно у марту, када је стопа инфекције била нижа, а да је одједном корисно у јуну.

Равнодушност према тестирању и праћењу, и отпор према ограничењу кретања и окупљања били су у складу са инсистирањем на томе да школе остану отворене и обавезне, чак и за оне у ризичним групама. Редовно се тврдило да деца не инфицирају друге и да затварање школа неће имати утицај на ширење вируса, што је било у супротности са растућом евиденцијом и извештајима о умирању учитеља у Шведској и броју деце на пријему у болницама. Јохан Карлсон, генерални директор ФоХМ-а, ту тврдњу је изнео 13. марта и додао да би затварање школа било непримерено јер деца не би имала где да иду (Fernstedt, Karlsson, 2020). Многи су сумњали у ово образложење, а након једног потврђеног случаја COVID-19 у школском кампусу Манила у Стокхолму почетком марта, директор је одлучио да привремено затвори школу. Случај је био посебно деликатан с обзиром на то да је ћерка крунске принцезе похађала ту школу. Државни епидемиолог је тим поводом био узнемирен и забринут да би то могли да следе и други директори школа; издавањем упутстава регионима желео је да осигура спречавање затварања школа (Delin, 2020).

Развој школског питања учинио је рањивим многе родитеље из ризичних група или са децом из ризичних група, с могућношћу или да зараде вирус или да, ако држе децу кући, буду кажњени због кршења закона о школама.

Питање отворених школа и обесхрабривање употребе маски за лице иду у прилог хипотези да је имунитет стада стратегија, чак иако су у вези с тим даване контрадикторне и често збуњујуће изјаве. Регионални службеници за контролу болести (Smittskiddslakare), који су недељно били у контакту са ФоХМ-ом, повремено су отворено иступали. Андерс Нистед, службеник за контролу болести за регион Норботен, тврдио је још 5. априла да је имунитет стада стратегија и представио циљ у пауер поинту (Niberg, 2020). И сам државни епидемиолог је често нагађао када се имунитет стада може постићи у земљи или у главном граду Стокхолму, са различитим датумима

27 Тестирање је вршено све време, али је било врло ограничено на хоспитализоване пацијенте и неке здравствене раднике.

28 Састанак за штампу са премијером, 4. јун 2020. Доступно на мрежи: https://www.regeringen. se/pressmeddelanden/2020/06/presstraff-med-statsministern-4-juni/ (приступљено 4. јуна 2020). 
предложеним у различито време ${ }^{29}$. Када су средином марта суседне државе затвориле своје границе, он се залагао против тога као погрешне стратегије (Svahn, 2020). Аника Линде, бивша државна епидемиолошкиња (2005-13), тврдила је почетком марта да би имунитет стада и омогућавање полаког ширења болести кроз школе и здраву одраслу популацију била пожељна стратегија (Linde, 2020). Касније ће се предомислити, али тврди да је то изгледа била шведска стратегија.

Најгласнији по питању имунитета стада био је Јохан Гисецке, бивши државни епидемиолог (1995-2005) а запослен као саветник ФоХМ-а, те ментор или блиски сарадник државног епидемиолога Тегнела. Гисецке је давао интервјуе у разним међународним медијима, тврдећи да је имунитет стада једина разумна стратегија (Russell, 2020; Kuann, 2020; Hardi, 2020; Saiers, 2020). Гисецке, претпостављни Тегнелу, често је у медијима био представљен као шведски ауторитет и Нестор по питању епидемиологије.

Док су Тегнел и Гисецке у медијима редовно давали процене када се може очекивати имунитет стада, истовремено је негирано да је то стратегија. Карин Тегмарк Висел из ФоХМ-а је 15. марта на шведском радију изјавила да имунитет стада није стратегија и да је циљ зауставити вирус ${ }^{30}$. У међувремену, државни епидемиолог Тегнел је изјавио да је идеја имунитета стада „делимично тачна”, али не и да је стратегија ${ }^{31}$. Даље, 16. маја, на једној од неколико уживо емитованих конференција за штампу, премијер је порекао да је имунитет стада стратегија: „Дозволите ми да такође подвучем да не постоји шведска стратегија за стварање имунитета стада као одговор на COVID-19. Имунитет стада је статус (сиц), а не стратегија" ${ }^{2}$. Дакле, у свим причама у јавности о имунитету стада и термину када би се то могло постићи, са отвореним школама и без маски за лице, било је тешко разликовати да ли се радило о смишљеној стратегији или само о претпостављеном неизбежном крајњем стању. Заштита ризичних група је била актуелна тврдња, чему је противречио немар по питању заштитне опреме у болницама и домовима за негу, као и ускраћивање кисеоника старијим особама из ризичних група, на шта ћемо се вратити ниже у тексту. Најзад, циљ је можда био заштита болничког система и економије.

Службеник за контролу болести (Smittskyddsläkare) из Стокхолма је 16. јуна изјавио да људи који су имали COVID-19 и даље могу ићи на посао ако имају само благе симптоме (Larsson, 2020).

${ }^{29}$ На пример Елиат Х.: Шведска се опирала ограничавању кретања, а очекује се да ће њен главни град Стокхолм достићи „имунитет стада” за неколико недеља. Доступно на мрежи: https://vvv.cnbc.com/2020/04/22/no-lockdovn-in-sveden-but-stockholm-could-see-herdimmuniti-in-veeks.html (приступљено 28. априла 2020); и https://sv.vikikuote.org/viki/Anders_ Tegnell\#Januari

${ }^{30}$ Strategin: Ska bromsa corona - till varje pris. Доступно на мрежи: https://www.expressen.se/ nyheter/strategin-lat-manga-smittas-i-lagom-takt/ (приступљено 15. марта 2020).

${ }^{31}$ Strategin: Ska bromsa corona - till varje pris. Доступно на мрежи: https://www.expressen.se/ nyheter/strategin-lat-manga-smittas-i-lagom-takt/ (приступљено 15. марта 2020).

32 Expressen Live TV 16 May 2020: Här pressas Löfven om corona av utländska joutnalister. Дocтупно на мрежи: https://www.expressen.se/tv/nyheter/coronaviruset/har-pressas-lofven-avutlandska-journalister-om-corona/ (приступљено 16. маја 2020). 
Још један случај обмањивања јавности догодио се у вези са PCR тестовима и антителима, где је ФоХМ прво пренела утисак да се COVID-19 брзо и свеобухватно ширио кроз популацију, док је стварно погађао само мали број, ширећи неутемељену претпоставку да је значајан број људи већ прележао инфекцију (Branden, 2020a). На исти начин ФоХМ обмањује јавност у вези са бројем људи који је развио антитела и имунитет (Branden, 2020b). Према истраживању медија, комуникација ФоХM-а била је у супротности са основним имунолошким знањем (Branden, 2020c).

Коначна илустрација слуђивања односи се на прикривање одговорности или њено потпуно негирање. Упркос хиљадама смртних случајева у домовима за негу, премијер је изјавио да то нема никакве везе са шведском стратегијом ${ }^{33}$. Ту се уопште није радило о било каквој владиној одговорности. Јохан Карлсон, генерални директор ФоХМ-a, је у јулу изнео тврдњу да је оно што се догодило у Шведској, од 8. јула, преко седам пута више умрлих на милион него све остале нордијске земље заједно, све случајност и лоша срећа ${ }^{34}$. Такође је тврдио да је свако поређење са другим нордијским земљама бесмислено и одбацио је њихове стратегије као неутемељене ${ }^{35}$.

На конференцији за новинаре 14. јула, новинар ЦБС-а је питао Карин Тегмарк Висел, портпаролку ФоХМ-а, о стратегији у светлу високе стопе смртности у Шведској, око четрдесет процената већој од Сједињених Држава, и добио одговор да поређење земаља у овом тренутку нема смисла ${ }^{36}$.

Генерални директор, државни епидемиолог и саветник Гисецке одбацио је стратегије које су следиле друге земље, посебно нордијски суседи, тврдећи да ће свака земља на крају имати исте стопе смртности ${ }^{37}$.

${ }^{33}$ Интервју премијера на СВТ Агенда, 14. јуна, 2020.

${ }^{34}$ Jani Pirttisslo Sallinen Carlsson: Slump att Sverige Drabbades. Доступно на мрежи: https://www. svd.se/carlson-coronadrabbat-sverige-var-en-slump (приступљено 10. јула 2020).

35 Jani Pirttisslo Sallinen Carlsson: Slump att Sverige Drabbades. Доступно на мрежи: https://www. svd.se/carlson-coronadrabbat-sverige-var-en-slump (приступљено 10. јула 2020).

36 https://www.svtplay.se/video/27534853/nyheter-direkt/myndigheternas-presstraff-om-coronalaget4? start=auto (од 38. минута) (приступљено 17. јула 2020).

37 Поново је Гиесецке био најгласнији по овом питању, одбацивши стратегије других земаља: Giesecke: Om ett ar ar ovriga Norden i kapp Sveriges dodstal. Доступно на мрежи: https://vvv.dn.se/niheter/ sverige/giesecke-om-ett-ar-ar-ovriga-norden-i-kapp-sveriges-dodstal/ (приступљено 10. маја 2020). Претпоставка коју подржава академски професор Јан Алберт: Lar bli jamna dodstal I Nordens lander. Доступно на мрежи: https://omni.se/professor-lar-bli-jamna-dodstal-i-nordens-lander/a/ kP2dJ8 (приступљено 10. маја 2020), док је државни епидемиолог Тегнел тврдио да Шведска има боље мере и статистику него било која друга земља: Tegnell: Darfor har Sverige hogre dodsfall (приступљено 11. априла 2020). Доступно на мрежи: https://vvv.svt.se/niheter/inrikes/ tegnell-darfor-har-sverige-hogre-dodstal i Berg Eidebo J. Tegnell: Darfor har Sverige hogre dodsfall (приступљено 11. априла 2020). Доступно на мрежи: https://vvv.gp.se/niheter/sverige/tegnelld\%C3\%A4rf\%C3\%B6r-har-sverige-h\%C3\%B6gre-d\%C3\%B6dstal-1.26674362. 21. маја државни епидемиолог Тегнел тврдио је да би шведски туристи били безбеднији за друге земље током лета, јер би Швеђани имали виши ниво имунитета стада: Scogelin M. Tegnell: svenska turister kan vara sakrare an andra. Доступно на мрежи: https://vvv.svd.se/tegnell-svenska-turister-kan-varasakrare (приступљено 21. маја 2020). Генерални директор Јохан Карлсон тврдио је да стопа смртности у Шведској нема никакве везе са стратегијом, већ се ради о апсолутном случају: Svenska Dagbladet. Доступно на мрежи: https://vvv.svd.se/carlson-coronadrabbat-sverige-var-en-slump; 
Порука Швеђанима била је да су све друге земље погрешно приступиле проблему, а да је само Шведска имала тачну анализу. Поруку је у интервјуу 16. јула потврдио премијер, који је изјавио да је шведска стратегија за лечење короне „потпуно исправна" (Johansson, 2020).

\section{Кисеоник или морфин?}

У априлу је шведски доктор медицине и окружни лекар Јон Талингер, називајући се Др узбуњивачем јавности, тврдио да су лекари добили препоруке за примену морфијума уместо кисеоника за старије људе у домовима за негу, имплицирајући активну еутаназију ${ }^{38}$. Тријажа је такође значила да пацијентима старијим од осамдесет година или преко шездесет пет година треба одбити третман на интензивној нези ако припадају ризичној групи, ради чувања места у јединицама интензивне неге ${ }^{39}$. Иако су званичници демантовали Талингерове тврдње, подржала их је и друга узбуњивачица, медицинска сестра Латифа Ловенберг, која је такође тврдила да је најмање десет људи умрло као резултат смерница за регион Гавлеборг (Eriksson, 2020). Након што је изашла у јавност са својом тврдњом, отпуштена је са посла. Иако су шведски медији у почетку игнорисали Талингерове тврдње, он их је на Јутјубу представио прилажући интервјуе и листајући билтене пацијената ${ }^{40}$.

Ингве Густавсон, професор геријатријске медицине на Универзитету у Умеи, је 18. маја у шведском медицинском часопису упозорио да су многи старији људи непотребно умрли док су били у домовима за негу уместо да су примљени у болницу, због чега им није пружена исправна медицинска процена или третман ${ }^{41}$.

Инспекција за здравство и негу (ИВО) је у априлу и мају започела истрагу ситуације у шведским домовима за негу ${ }^{42}$. ИВО је 20. маја изјавила да је покренута већа истрага након запажања ИВО-е и извештаја о старијим особама којима није пружен третман кисеоником. ИВО је 7. јула предочила потпуни извештај на националном нивоу, те да је неколико региона изашло са почетном проценом да старије особе не

38 Доступно на мрежи: https://www.youtube.com/watch?v=Csb9DvAUj_s (приступљено 8. јула 2020) и https://www.youtube.com/watch?v=xk0TK_Syn9I\&t=592s (приступљено 8. јула 2020).

${ }^{39}$ На конференцији за новинаре 26. марта, Томас Линден, из руководеће групе шведског Националног одбора за здравство и социјалну заштиту (Socialstirelsen), објаснио је којим пацијентима би евентуално могло да буде ускраћено лечење: "Brackliga personer kan snart nekas coronavard”. Доступно на мрежи: https://vvv.ekakt24.se/brackliga-personer-kan-snartnekas-coronavard/ (приступљено 26. марта 2020).

${ }^{40}$ На пример овде: доступно на мрежи: https://www.youtube.com/watch?v=LeMSieNQwUQ (приступљено 8. јула 2020).

${ }^{41}$ Läkartidningen (Swedish Medical Journal) 18 May: Ohlin E. Geriatrik professor: Många äldre dör i unödan utan korrekt bedömning. Доступно на мрежи: https://akartidningen.se/aktuellt/ nyheter/2020/05/geriatrikprofessor-manga-aldre-dor-i-onodan-utan-korrekt-bedomning/

${ }^{42}$ IVO 20 мај, 2020: Tillsyn av vård och behandling på landets samtliga särskilda boende för äldre. Доступно на мрежи: https://www.ivo.se/publicerat-material/nyheter/2020/tillsyn-av-vard-ochbehandling-pa-landets-samtliga-sarskilda-boenden-for-aldre/ (приступљено 17. јула 2020). 
треба слати на болничку негу без обзира на потребе, већ их треба држати у домовима за негу ${ }^{43}$. Међутим, с повећањем капацитета, од те праксе се одустало.

До јула месеца је неколико сличних инцидената стигло до међународних медија. Финска медицинска сестра која је радила у Шведској је 7. јула рекла листу Yle да су смрт старијих особа у Шведској убрзали лекари који су преписивали морфијум и слали на палијативну негу, понекад чак и без виђења пацијента ${ }^{44}$. Потврдила је и то да је пацијентима ускраћен кисеоник. Пракса ускраћивања интензивне неге за пацијенте старије од осамдесет година даље је обрађена у медијима кроз случај осамдесетједногодишњака коме је ускраћена интензивна нега иако је у болници било расположивог простора (Erlandsson, 2020). ЦБС њуз је 16. јула емитовао интервју из Стокхолма са женом чији је осамдесетогодишњи отац који живи у дому за негу имао дијагнозу COVID-19, али је уместо трансфера у болницу добио морфијум и на крају умро без лечења ${ }^{45}$.

Средином јула, током текуће националне провере ИВО-а, отприлике један од пет региона (Шведска има 21 регион) пријавило је ИВО-у да је палијативно збрињавање превремено успостављено током ране фазе пандемије и да су одлуке за то пре биле опште него појединачне ${ }^{46}$.

\section{Забрана заштитне опреме}

Поред тога што нису имали маске за лице или заштитну опрему, неколико домова за негу у Шведској имало је и инциденте са уклањањем постојеће опреме, попут дезинфекције за руке или забране приватне употребе маски за лице. Особље у једном дому за негу у Стокхолму известило је да је дезинфекција за руке држана под кључем, а да је дозвољено изношење само у случају посете медија ${ }^{47}$.

Старија жена која живи као станарка у дому за негу у општини Готен пријавила је шведском радију да жели да се заштити сопственом маском за лице, али јој је особље то забранило уз аргумент да то делује застрашујуће ${ }^{48}$.

${ }^{43}$ Tillsyn av vård och behandling på landets samtliga särskilda boende för äldre. Доступно на мрежи: https://www.ivo.se/publicerat-material/nyheter/2020/ivo-fordjupar-granskningen-av-vardoch-behandling-pa-sarskilda-boenden-for-aldre/ (приступљено 17. јула 2020).

44 Доступно на мрежи: https://yle.fi/uutiset/3-11433976 (са изводима на шведском: Sverige bilden. "I Sverige har äldre människors död påskyndets med morfinsprutor"). Доступно на мрежи: https://meritwager.nu/allmant/sverigebilden-i-sverige-har-aldre-manniskors-dod-paskyndatsmed-morfinsprutor/) (приступљено 9. јула 2020).

45 CBS News 16. јул Доступно на мрежи: https://www.cbsnews.com/video/sweden-sees-high-virusmortality-rate-after-resisting-lockdown/ (приступљено 17. јула 2020).

${ }^{46}$ Dagens Nyheter 18. јул 2020: Flera regioner: Palliativ vård sattes in för snabbt. Доступно на мрежи: https://www.dn.se/nyheter/sverige/flera-regioner-palliativ-vard-sattes-in-for-snabbt/ (приступљено 18. јула 2020).

47 Expressen, 17. мај 2020: Larm från boendet: "Vi tigger för att få handsprit". Доступно на мрежи: https://www.expressen.se/nyheter/coronaviruset/larm-fran-boendet-vi-tigger-for-att-fa-handsprit/

${ }^{48}$ SR (Swedish Radio) 15. мај 2020. 


\section{Искуство терора у свакодневном животу}

У свом класичном тексту из области студија међународне безбедности Бери Бузан је саму државу истакао као потенцијални извор угрожавања личне безбедности (Buzan, 1983). Узимајући појединца и људе као несводиву основну јединицу на коју се безбедност односи, јасно је да држава може бити и штит који пружа сигурност, а и претња по њу. У хобсовском смислу држава може да спречи анархију, да обезбеди социјалну стабилност, закон и ред и физичку заштиту, али с друге стране држава такође може да интервенише на начине који умањују личну сигурност. Аспект индивидуалне безбедности су социјалне претње, оне које проистичу из чињенице да су људи усађени у људску средину (Buzan, 1983, str. 19). Концепти попут слабих држава, крхкости државе или пропалих држава односе се на ситуације када држава не успева или није у стању да обезбеди основне безбедносне, здравствене или социјалне услуге. Али држава такође може створити несигурност разоткривањем или циљањем појединаца, мањина или грађана, или у најгорим случајевима постати инструмент терора.

Несигурност је за многе грађане Шведске постала стварно искуство током пролећа 2020. године, јер је њихов свакодневни живот подлегао биополитичком експерименту који је дозволила држава. Последица горепоменутих мера и услова је за делове популације било искуство тескобе и страха у свакодневном животу. Ово је подстакнуто стратегијом и предузетим или непредузетим радњама, као и самом пандемијом. За старије људе који живе у домовима за негу или користе општинску кућну негу, кућну услугу, свакодневне посете неговатеља без заштитних маски подразумевале су потенцијалну посету анђела смрти. И домари су били изложени, нису смели да користе заштитну опрему у свакодневном обиласку. Анксиозност везана за ове услуге се преносила и на брижне рођаке. Крајњи терор био је, наравно, у вези са вестима о тријажи и ускраћивању интензивне неге за одређене старосне или ризичне групе. Поверење у здравствену заштиту се одједном нашло под знаком питања.

Сличну узнемиреност искусили су наставници и родитељи из ризичних група, који су били приморани да раде или децу шаљу у школу. То је такође подразумевало свакодневно одлучивање и балансирање између кршења закона и ризика од заразе. Неконтролисано ширење у друштву такође је значило да су они у ризичним групама или у старијим старосним групама били ограничени на временски недефинисану самоизолацију или би, у супротном, били изложени ризику. Појавиле су се Фејсбук групе и групе за подршку родитељима, забринутим грађанима и онима који су већ имали COVID-19, али су искусили дугорочне последице или нежељене ефекте ${ }^{49}$.

Као и у неким другим земљама, пандемија је политизована. Као да је оштра линија раздвајања пресекла становништво на оне који доживљавају терор и оне који подржавају стратегију. Иако за неке свакодневни терор, пандемија је праћена јавним и медијским жаром корона национализма.

49 Потоња Фејсбук група имала је око 11.000 чланова до јуна 2020. О дугорочно погођеним видети такође: Vi ar tusentals som aldrig ticks bli friska - hjalp oss! Доступно на мрежи: https:// vvv.ekpressen.se/debatt/vi-ar-tusentals-som-aldrig-ticks-bli-friska-hjalp-oss/ (приступљено 17. јула 2020). 


\section{Корона национализам}

Упркос нордијском рекорду у смртности и месту међу пет најтеже погођених земаља на свету, у шведским медијима и широј јавности уочљива је била подршка влади и ФоХМ-у током пролећа 2020. године ${ }^{50}$. До априла, поверење у ФоХМ је порасло на 73 процента ${ }^{51}$. Приватници су агенцију преплавили цвећем, а појавила се и Фејсбук група подршке државном епидемиологу Тегнелу ${ }^{52}$. Мајице и шоље за кафу са његовим именом су се производиле и продавале, а појединци су радили нове тетоваже са његовим ликом или именом ${ }^{53}$. Израђиване су дрвене скулптуре и слике (Hoog, 2020). Хроничари у медијима су исмевали неистомишљенике, који су понекад били означавани као „хоби епидемолози”, иако су многи критичари били професори из релевантних медицинских области. И сам државни епидемиолог редовно је отпуштао све критичаре. Порука владе и ФоХМ-а била је да је Шведска једина држава на свету која је ово урадила на прави начин. Суседне Данска и Норвешка критиковане су и понекад третиране као ирелевантне, уз тврдњу да ће њихове стопе смртности ускоро достићи Шведску ${ }^{54}$. До краја маја то је резултирало дипломатским инцидентом, где је италијански амбасадор у Шведској критиковао државног епидемиолога Тегнела због давања погрдних коментара на рачун Италије и италијанског здравства ${ }^{55}$. Амбасадор је такође истакао да је италијански здравствени систем према С3О рангиран боље од шведског и да Шведска, уместо да јавно ниподаштава друге земље, борбу против пандемије треба да посматра као заједнички циљ. Државном епидемиологу је током лета понуђен сат времена као водитељу на националном радију, да прича нацији директно о себи или на слободно изабрану тему, где је објавио да је био шокиран када су друге државе прешле на режим ограничења кретања ${ }^{56}$.

Без обзира на друге ефекте, пандемија је ојачала урођени шведски национализам и слику о себи као бољој од остатка света (Hoog, 2020). Међутим, ово се разликује од конвенционалног национализма у том смислу што се не односи директно

50 До јула 2020. године Шведска је била међу седам најгоре погођених земаља, а међу пет ако се искључе микро државе Сан Марино и Андора, по броју мртвих на милион становника.

51 Coronastatus 0420. Доступно на мрежи: https://novus.se/coronastatus-0420-2/ (приступљено 17. јула 2020).

52 Доступно на мрежи: https://www.washingtonpost.com/politics/2020/05/03/risk-swedenscoronavirus-strategy-blind-patriotism/

53 Доступно на мрежи: https://www.washingtonpost.com/politics/2020/05/03/risk-swedenscoronavirus-strategy-blind-patriotism/

54 Liknande prognoser I Skandinavien. Доступно на мрежи: https://www.aftonbladet.se/nyheter/a/ kJOJ7B/liknande-virusprognoser-i-skandinavien; државни епидемиолог тврди у чланку од 6. марта да међу нордијским земљама не треба очекивати никакве разлике у бројевима.

55 На пример СвД 27. мај 2020: Grönberg A. Italiens ambassadör riktar kritik mot Anders Tegnell. Доступно на мрежи: https://www.svd.se/italiens-ambassador-kritiserar-tegnell (приступљено 17. јула 2020).

56 Tegnell: “Som om världen blev galen”. Доступно на мрежи: https://www.svt.se/nyheter/inrikes/ tegnell-som-om-varlden-blev-galen (приступљено 17. јула 2020). 
на нацију ${ }^{57}$. У том смислу ради се о прикривеном или скривеном национализму, који иако никада не помиње нацију, садржи имиџ сопствене грандиозности и ксенофобичне дистанце према „другом”, што се може објаснити социјално-психолошким терминима. Део прикривеног или скривеног национализма је и то што се позивање на саму нацију сматра инфериорним или нижим. То је део ирационалне романтичне прошлости у коју су укључени „други”. Шведски прикривени или скривени национализам хвали шведску супериорну рационалност, секуларизам, толеранцију, флексибилност и отвореност. У контексту пандемије, шведски пут или изузетност се види као израз ове рационалности. На пример, за разлику од других, Швеђани не паниче.

Свакодневно понашање индивидуа такође би се могло тумачити као подела између националистичке подршке и неистомишљеника. Однос према ношењу маски за лице, које се ни до 20. јула углавном нису користиле, могао би се сматрати неслагањем, а лист The Local објавио је да су се страни становници жалили на ксенофобично злостављање, те да се на њих кашљало због јавног ношења маски ${ }^{58}$.

Овај феномен праћен је у Шведској обрасцем према којем брендирање и слика постају све важнији у политичком животу, са посебном заокупљеношћу имиџом Шведске у иностранству. У том контексту се критике Шведске, посебно пред међународном публиком, могу сматрати непатриотским и нелојалним према земљи. Слична реакција догодила се након мигрантског таласа у јесен 2015. године, када је Шведска примила знатно више избеглица по становнику него суседне земље или друге земље у ЕУ.

Када су поједини истраживачи, полицијски службеници и узбуњивачи јавности критиковали неуспелу избегличку, миграциону или интеграциону политику или извештавали о повећаним стопама криминала, били су обично игнорисани или маргинализовани док се критика није појавила у међународним медијима. Када се ово друго догодило, изазвало је снажне реакције где су и премијер и министар правде, и бивши премијер и министар спољних послова напали грађане у штампи оцењујући њихову критику као нелојалну ${ }^{59}$. Када је ауторка књига за децу Катерина Јанух критиковала шведску политику у чешким медијима, и када је опозициони лидер то учинио у Вол стрит журналу, министар правде је тврдио да таква критика може бити лоша за шведско пословање па су књижаре уклониле Јанухине књиге са полица ${ }^{60}$. За Шведску, земљу која је у великој мери зависна од извоза, само име државе је важно и штите га Влада и медији. Међутим, када се од појединачних грађана очекује или тражи да се придржавају дискурса који чува слику о органском погледу на државу у којој се грађани виде као проширени делови државног организма, тада је култура слободе говора угрожена.

57 Отуда се његово изражавање разликује од онога што је типично описано у литератури и теоријама национализма, било да се ради о модернизму, конструктивизму (тj. Ernest Gellner, Benedict Anderson, Eric Hobsbavm) или вишегодишњем трајању (нпр. Smith), као што је изложено у Smith, A. (2020).

58 Sörensen, J. S. (17. јул 2020). “Skadligt att Sverige drivs som ett varumärke”. Svenska Dagbladet. Доступно на мрежи: https://www.svd.se/skadligt-att-sverige-drivs-som-ett-varumarke [На шведском]

${ }^{59}$ Sörensen, J. S. "Skadligt att Sverige drivs som ett varumärke”. Доступно на мрежи: https://www. svd.se/skadligt-att-sverige-drivs-som-ett-varumarke (приступљено 17. јула 2020).

${ }^{60}$ Sörensen, J. S. "Skadligt att Sverige drivs som ett varumärke”. Доступно на мрежи: https://www. svd.se/skadligt-att-sverige-drivs-som-ett-varumarke (приступљено 17. јула 2020). 


\section{Постајући неприпремљен}

Иако је Влада наложила ФХМ-у да 31. марта настави тестирање и поново је 7. јуна у телевизијској дебати политичких странака најавила додатна тестирања, то још увек није настављено у неком већем обиму до средине јула ${ }^{61}$. Иако су региони сада добили упутства да наставе тестирање и праћење, то нису били у могућности да спроведу. Објављено је 2. јуна да региони Стокхолма и Упсале немају такав капацитет и да су тражили од пацијената да то учине сами, без даљег праћења или контроле ${ }^{62}$. Ово је било у директној супротности са препорукама СЗО за тестирање и праћење.

Ово је показало општији образац неприпремљености, што је такође био случај са маскама за лице у домовима за старе и у услугама, или са маскама за кисеоник у домовима за негу, или са респираторима у болницама.

За Шведску је неприпремљеност довела до тога да се пандемија укаже попут онога што је Николас Насим Талеб назвао „црним лабудом” (Nassim, 2007). Црни лабуд је метафора догађаја који је изузетно редак и мало вероватан, али који има огромне последице, на пример удар астероида који је угасио живот диносауруса. Међутим, иако су пандемије ретке, оне су догађаји који се понављају неколико пута сваког века. Отуда они нису догађај црног лабуда и за њих је могуће бити спре-

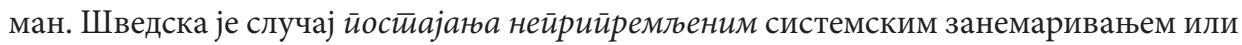
неспособношћу у погледу управљања кризама. У анатомији неприпремљености, две компоненте су од посебне важности: 1) настајање Владе са нејасном структуром надлежности и одговорности између министарстава, државних агенција, региона, општина и приватних послодаваца, и 2) јавна управа са институцијама засићеним бројним политичким, идеолошким и економским циљевима изван својих основних функција и под сталним економским стресом.

Први проблем са нејасним одговорностима је већ поменут, али недавни пример недоследности је додатно поучан. Влада тврди да није одговорна за домове за негу и да је ово стриктно општинска одговорност, баш као што тврди да није одговорна ни за здравствену заштиту, ни за тестирање и праћење, што је регионална одговорност. Ипак, Влада је под вођством Министарства за социјална питања (Socialdepartementet) почетком марта имала вежбу за кризни сценарио, на коју је позвала агенције ФоХМ и Socialstirelsen, а једна од тачака дневног реда били су домови за негу (Sundkvist \& Simon, 2020). Ипак, Влада је одлучила да се по том питању усредсреди само на то како у здравственој заштити под снажним притиском сачувати одрживост (Sundkvist i Larsson, 2020).

Постати неприпремљен је процес који траје од демонтаже цивилне одбране, и смањења и преношења на спољне добављаче владиних институција још од деведесетих година прошлог века. Слабост у управљању кризама била је видљива и раније, као што је то било током олује 2005. године, цунамија 2008. године и масовног безбедносног скандала у вези са цурењем и преношењем осетљивих и поверљивих информација из Transportstirelsen-a у 2018. години. Конкретан случај је спор одговор за

${ }^{61}$ Folkhälsomyndigheten får i uppdrag att testa bredare. Доступно на мрежи: https://www.svt.se/ nyheter/inrikes/folkhalsomyndigheten-far-i-uppdrag-att-testa-bredare

62 Sveriges Radio, Ekot, 2. јуни 2020. "Ansvar för smittspårning läggs på patienter”. 
поновно успостављање снабдевања топлотном и електричном енергијом током олује Гудрун на југу Шведске у јануару 2005. године. Олуја је имала снажан ефекат на телекомуникације и електроенергетске мреже, а 730.000 људи је усред шведске зиме било искључено са мреже топлотне и електричне енергије. Прошло је пуних 45 дана пре него што се снабдевање топлотном и електричном енергијом у потпуности обновило $^{63}$. Иако су олује и природне катастрофе увек погађале људска друштва, ниво припремљености се разликовао. Пре демонтаже и приватизације шведске агенције за телекомуникације (Televerket) 1993. године, каблови, телефонски стубови и друга опрема били су на складишту, а агенција је имала око 45.000 запослених. Стандард за обнављање снабдевања у случају прекида електричне енергије током већих кварова био је један дан, или два током викенда. Иако је тешко упоредити штету и потребе за поправком између временских периода, демонтирање складишта и општа припремљеност за кризу сигурно игра улогу у овим догађајима. Што се тиче болничких и средстава за интензивну негу, конкретан случај се односи на демонтирање цивилне одбране и пољских болница. Шведска је 1990. године имала педесет пољских болница (од тога 15 морских). Теренске болнице имале су по шест оперативних сала, а свака сала је имала шеснаест респиратора. Све је то расходовано током 1990-их, а до 2020. године остала је само једна нетакнута.

Општији образац је смањење јавног сектора смањењем или укидањем резерви током три деценије такозваних реформи новог јавног управљања (НЈУ). Иако НЈУ једва да је специфичан појам, већ је кровни термин за стотине различитих реформи у различитим секторима и земљама, они ипак деле исту базу неолибералне филозофије да је тржиште најбољи процесор информација и да принципи опонашања тржишта треба да буду уведени у јавни сектог ${ }^{64}$. Дакле, НЈУ садржи филозофију управљања која је у супротности са етосом јавне управе који јој је претходио (Lundkuist, 2001). Иако се уклањање резерви и спремност морају анализирати у контексту завршетка хладног рата, на делу су и јавна управљачка и структурна компонента. Увођење тржишне логике је у многим организацијама резултирало стресом система, са мањим маржама и ресурсима за неочекиване догађаје.

\section{Тоталитарна демократија}

Фински историчар и културни критичар Јари Ернрот сугерисао је да шведска стратегија за корону открива како је Шведска постала мека верзија онога што он назива тоталитарном демократијом (Ehrnrooth, 2020). Концепт тоталитарне демократије развио је Јакоб Талмон како би супротставио две традиције демократије настале Француском револуцијом: либералну и тоталитарну (Talmon, 1952/1970). Напетост између те две традиције је витално питање нашег времена. Либерална струја не само да наглашава појединачна права и слободе, већ и на политику гледа као на процес покушаја и грешака који води заједничку судбину и препознаје појединачне и

${ }^{63}$ Svt "Strömavbrott vi minns": Доступно на мрежи: https://www.svt.se/special/stromavbrott-viminns/ (приступљено 17. јула 2020).

64 Творац термина је Кристофер Худ у тексту из 1991. године. За добру расправу и критичку евалуацију новог јавног менаџмента у Британији види Hood, C \& R. Dixon (2015). 
колективне напоре ван политике. Људски живот се одвија и води кроз многе сфере, од којих је једна политичка. Тоталитарни облик, насупрот томе, верује у тоталну и искључиву истину у политици, до које они који владају морају водити друштво. Ово је месијански облик политике где се коначни циљ политике постиже тек када те истине или веровања завладају свим сферама живота, па је према томе тоталитаран. Политика је једноставно уметност примене ове филозофије на организацију друштва. Месијански је у смислу да постулира поредак или начин живота до којег људи морају доћи и сматра да политика обухвата све сфере живота. Обе традиције цене „слободу”, али док је либерал посматра у смислу спонтаности и одсуства принуде, тоталитаристи је виде остварену само у постизању апсолутне колективне сврхе (Talmon, 1952/1970, стр. 2).

Концепт помаже у осветљавању преласка из либералне фазе у радикалну фазу Француске револуције током 1791-92. године и погледа на демократију Робеспјеровог одбора за јавну безбедност током „владавине терора”, када је република режирала насиље против сопствених грађана, или на Русоов концепт „опште воље”, где се ако воља народа не постоји он „мора натерати на вољу” (Talmon, 1952/1970, стр. 43). Политички месијанизам углавном је повезан са револуционарним покретима или са тоталитарним диктатурама с десне или леве стране. На пример, кинеска културна револуција био је такав месијански политички програм чишћења усмерен на појединце са „погрешном вољом” или мишљу.

Према Ернроту, шведски случај манифестује друштво у којем се једнообразност ставља изнад плурализма, а где просек чини државна прогресивна доктрина са месијанским сном о социјалном миру (Ehrnrooth, 2020). У таквом систему, окупљање под окриљем државне идеологије и изражавање корона национализма уобичајен је покрет ка друштвеном добру, а сваки дисидент је антисоцијални јеретик.

Месијански аспект шведске политике приметио је и шведски историчар Сванте Нордин у свом недавном раду о шведској модерној историји (Nordin, 2018). Од 1809. године, примећује Нордин, или од непосредних последица Француске револуције, шведску политику карактерише пет главних таласа или струја политичких реформи, где се у свакој Шведска представљала у самопоуздању рационалне хипермодерности и као авангарда у Европи и свету, и где је такође сваки пројекат одбацио претходни као део декадентне прошлости ${ }^{65}$. Иако Нордин не користи Талмонсову терминологију, његово дело се може читати као дубља историјска илустрација антиконзервативног политичког месијанизма. Овакав поглед на политику ипак је усидрен у уверењу да Шведска има дубоко укорењену демократску традицију, али поента парадоксалног концепта тоталитарне демократије је да тоталитаризам има одушевљену подршку народа.

Штавише, за разлику од историјских тоталитарних држава, тоталитарна демократија дозвољава критику, а систем власти је представничка демократија са изабраном владом. Али, без обзира на критику, чак и ако је заснована на науци, нема корекције. То добро илуструје изостанак уважавања међународних истраживачких

65 То укључује Устав 1809. године, парламентарну реформу 1866. године, увођење општег бирачког права, „Дом народа” и социјалну државу од 1930-их, као и глобализацију и мултикултурализам у последњих 30-40 година. 
налаза и студија о различитим аспектима COVID-19, од постојања пресимптоматског и асимптоматског ширења, корисности употребе маски за лице, важности тестирања и праћења, трајности антитела, утицаја болести на децу, до извештаја о потенцијалним дугорочним оштећењима ${ }^{66}$. Без обзира на забрињавајуће извештаје и налазе који су се надовезивали на ове аспекте, шведска влада и ФоХМ остали су непоколебани и није било промене стратегије или чак размишљања на ту тему.

Неколико фактора може симултано овде бити у игри. Иако је о национализму и националном поносу већ било речи, постоји и елемент институционалне крутости, при чему институција или организација реагује на спољну критику штитећи се збијањем редова. Феномен когнитивне дисонанце, како га је 1950-их описао и теоретизовао Леон Фестингер, може бити посебно релевантан јер садржи низ напредних психолошких механизама за порицање и одбацивање било каквих доказа у супротности са устаљеним веровањима или који генеришу емоционални стрес (Festinger , 1957). Мора се претпоставити да когнитивна дисонанца игра значајну улогу у Шведској, барем у погледу понашања популуса. Други фактор може бити институционално заробљавање појединца или групе појединаца са одређеним психолошким карактеристикама. Ипак, концепт тоталитарне демократије пружа визуру за дубље разумевање политичке културе. Разлог непостојања већег дисидентског покрета је колективистички менталитет у којем је индивидуални живот подређен колективу.

\section{Закључак}

Шведски одговор на пандемију COVID-19 током пролећа-лета 2020. године истакао се као екстремно неуобичајен на међународном нивоу. Опуштени приступ остао је неупитан, без обзира на пораст стопе смртности и сврставање Шведске међу седам најтеже погођених земаља на свету, без обзира на суочавање са међународним критичким реакцијама или чак новим налазима истраживања који би дали разлога за забринутост. За многе Швеђане, који нису могли да се заштите у домовима за негу, старије који користе кућну услугу, родитеље или децу школског узраста из ризичних група или друге људе из ризичних група, стање је током ширења COVID-19 у пролеће 2020. године све више наликовало тиранији или терору. Иако је пандемија, баш као и у многим другим земљама, поделила становништво и створила нове структуре, такође је показала изузетну подршку Влади, макар у почетку. Ово је укључило већину националних медија. Неистомишљеници су били маргинализовани, ућуткивани или исмевани. Неколико фактора може бити потребно да се ово објасни, укључујући когнитивну дисонанцу, слуђивање и национални понос, али откривена је дубља политичка култура у којој се Шведска може разумети кроз појмове месијанског радикализма и тоталитарне демократије. Пандемија је такође изнела у први план низ постојећих нефункционалних аспеката државе, како на административном, тако и на законском и уставном нивоу. Манипулација или ускраћивање

66 Док су током пролећа 2020. године постојале студије случаја и извештаји о некима од њих, на пример извештаји о асимптоматском ширењу и корисности маски за лице, или о дугорочним ефектима и хроничним оштећењима, до средине јула 2020. године појавио се значајан број забрињавајућих извештаја и студија о свим поменутим аспектима. 
информација, како између грана јавног сектора и Владе, тако и између јавног сектора и становништва, тајност и заташкавање, открили су дубоко укорењене проблеме демократије и транспарентности у држави. Недостатак опреме, проблеми у организацији и етички упитне праксе разоткрили су дубоке преломе у систему социјалне заштите и у читавом шведском моделу. Изложеност ризичним групама, лечење старијих особа и институционална неспособност да усвоје и прилагоде се новим информацијама, вероватно ће бити фактори са дубоким и дугорочним последицама у шведском друштву и у јавној расправи. На међународном нивоу, утопијски сан Шведске да буде узор као друштво општег благостања, солидарности и хуманитарна велесила, ефективно се угушио у пандемији COVID-19.

\section{REFERENCES / ЛИТЕРATУРA}

Arpi, I. (2020, May 15). Kritiker avfärdas som coronagalna. Svenska Dagbladet. Available at: https://www.svd.se/kritiker-avfardas-som-coronagalna][In Swedish]

Bränden, H. (2020a, June 9). Folkhälsomyndegheten vilseledde om PCR-testerna. Altinget. Available at: https://www.altinget.se/artikel/folkhalsomyndigheten-vilseledde-om-pcr-testerna [In Swedish]

Bränden, H. (2020b, June 11). Folkhälsomyndegheten vilseledde även om antikroppstesterna. Altinget. Available at:https://www.altinget.se/artikel/folkhalsomyn. digheten-vilseledde-aven-om-antikroppstesterna [In Swedish]

Bränden, H. (2020c, June 11). Folkhälsomyndegheten vilseledde även om antikroppstesterna. Altinget. Available at: https://www.altinget.se/artikel/folkhalsomyndigheten-vilseledde-aven-om-antikroppstesterna[In Swedish]

Buzan, B. (1983). People, States and Fear: The National Security Problem in International Relations, Harvester Wheatsheaf

Caracciolo, B. (2020, July 17). How the Mitigation Strategy tempted Northern Europe and Convinced only Sweden, Medium, Available at:https://medium.com/@barbara.caracciolo2020/how-the-mitigation-strategy-tempted-northern-europe-and-convinced-only-sweden-f6fb9197d49a

Delin, M. (2020, March 11). Statsepidemiolog Anders Tegnell: Sverige har väldigt svårt att acceptera risker. Dagens Nyheter. Available at: https://www.dn.se/nyheter/sverige/ statsepidemiolog-anders-tegnell-sverige-har-valdigt-svart-att-acceptera-risker] [In Swedish]

Ehrnrooth, J. (2020, July 10). Den svenska coronastrategin tecken på totalitär utveckling. Expressen. Available at: https://www.expressen.se/debatt/den-svenska-coronastrategin-tecken-pa-totalitar-utveckling/[In Swedish]

Eriksson, I. (2020, May 5). Sjuksköterska fick sparken efter larm om att äldre nekas syrgas. NB Nyhetsbyrån. Available at https://nyhetsbyran.org/2020/05/05/sjukskoterska-ficksparken-efter-larm-om-att-aldre-nekas-syrgas/ [In Swedish]

Erlandsson, A. (2020, July 8). Reglerna följdes inte när Gösta, 81, nekades vård. Svenska Dagbladet. Available at: https://www.svd.se/reglerna-foljdes-inte-nar-gosta-81, nekades-vard [In Swedish] 
Fernstedt, N. \& Karlsson, P. (2020, March 17). Brandtalet: därför kan vi inte stänga skolorna. Aftonbladet. Available at https://www.aftonbladet.se/nyheter/a/GGm881/brandtalet-darfor-kan-vi-inte-stanga-skolorna [In Swedish]

Festinger, L. (1957). A Theory of Cognitive Dissonance, Stanford University Press.

Hardy, J. (2020, May 6). Britain's COVID-19 lockdown was futile, says Swedish epidemiologist. The Telegraph. Available at: https://www.telegraph.co.uk/news/2020/05/06/britains-lockdown-futile-says-swedish-epidemiologist,

Hood, C \& R. Dixon (2015). A Government that Worked Better and Cost Less?: Evaluating three decades of reform and change in the U.K. Oxford University Press

Höög, M. (2020, July 8). Tegnell-dyrkandet visar skadlig del av vår kultur. Expressen. Available at: https://www.expressen.se/debatt/tegnell-dyrkandet-visar-skadlig-del-av-varkultur] [In Swedish]

Johansson, A. (2020, July 16). Stefan Löfven I stor intervju: "Svenska coronastrategin rätt". Aftonbladet. Available at:https://www.aftonbladet.se/nyheter/a/4q5jG6/stefan-lofven-i-stor-intervju-svenska-coronastrategin-ratt [In Swedish]

Karlsson P. (2020, March 13). Nya stratigin - slutar räkna exakta antalet coronafall. Aftonbladet. Available at:https://www.aftonbladet.se/nyheter/samhalle/a/70GQRV/nya-strategin--slutar-rakna-exakta-antalet-coronafall[In Swedish]

Larsson, S. (2020, June 16). Stockholmare kan gå till jobbet med milda symptom. Expressen. Available at:https://www.expressen.se/nyheter/stockholmare-kan-ga-till-jobbet-med symptom-1, [In Swedish]

Linde, A. (2020, March 14). Förra statsepidemiologen: "Långsam spridning kan bygga upp immunitete". Dagens Nyheter. Available at:https://www.dn.se/nyheter/sverige/for ra-statsepidemiologen-langsam-spridning-kan-bygga-upp-immunitet/[In Swedish]

Lundquist, L. (2001). Medborgardemokratin och eliterna. Lund political studies, Lund: Studentlitteratur. [In Swedish]

Lundquist, L. (2012). Slutet på yttrandefriheten (och demokratin?). Stockholm: Carlsson bokförlag. [In Swedish]

Nassim, N. T. (2007). The Black Swan, Random House.

Nordin, S. (2019). Sveriges moderna historia: Fem politiska projekt, 1809-2019. Natur \& Kultur. [In Swedish]

Nyberg, M. (2020, April 5). Nästan alla norrbottningar kommer att drabbas av COVID-19. SVT Nyheter. Available at:https://www.svt.se/nyheter/lokalt/norrbotten/nastan-al la-norrbottningar-drabbas [In Swedish]

Pihl, K. (2020, June 1). Myndigheternas mygel skadar både äldreomsorg och allmänhetens förtroende. Göteborgs-Posten. Available at:https://www.gp.se/ledare/myndigheternas-mygel-skadar-b\%C3\%A5de-\%C3\%A4ldreomsorg-och-allm\%C3\%A4nhetens-f\%C3\%B6rtroende-1.28586073][In Swedish]

Pirodsky, J. (2020, June 30). Czech Republic upgrades UK to low risk status, Portugal to medium risk for post COVID-19. Expats.cz. Available at:https://news.expats.cz/coronavirus-in-the-czech-republic/czech-republic-upgrades-uk-to-low-risk-status-portugal-to-medium-risk-for-post-COVID-19-travel/

Quann, J. (2020, May 15). Swedish expert: Irish lockdown "pushing serious cases into the future". Newstalk. Available at: https://www.newstalk.com/news/swedish-expert-irish-lockdown-pushing-serious-cases-future-1015773 
Russell, D. (2020, April 24). Sweden's former state epidemiologist: The end results of Covid-19 in Europe will be similar. Radio Sweden. Available at:https://sverigesradio.se/sida/ artikel.aspx?programid=2054\&artikel=7459717

Sayers, F. (2020, April 17). Swedish expert: why lockdowns are the wrong policy. The Post. Available at:https://unherd.com/thepost/coming-up-epidemiologist-prof-johan-giesecke-shares-lessons-from-swedent

Schneider, L. (2020, April 7). Swedish scientists call for evidence-based policy on COVID-19. For Better Science. Available at:https://forbetterscience.com/2020/04/07/swedish-scientists-call-for-evidence-based-policy-on-COVID-19/

Smith, A. (2020). Nationalism: Theory, Ideology, History. Cambridge: Polity Press.

Sörensen, J., \& Olsson, E. J. (2020). Shadow Management: Neoliberalism and the Erosion of Democratic Legitimacy through Ombudsmen with Case Studies from Swedish Higher Education. Societies, 10 (2), 30.https://doi.org/10.3390/soc10020030

Sundkvist, F. \& Larsson, S. (2020, July 2). "Regeringen skulle öva - valde bort äldreboenden", Expressen [In Swedish]

Svahn, C. (2020, March 14). Smittskyddsexperter dömer ut stängda gränser. Dagens Nyheter. Available at:https://www.dn.se/nyheter/sverige/smittskyddsexperter-domer-ut-stangda-granser/ [In Swedish]

Talmon, J. L. (1952/1970). The Origins of Totalitarian Democracy, W.W Norton

Wålsten, L. (2020, May 29). Myndigheter frestas att radera mejl. Svenska Dagbladet. Available at:https://www.svd.se/myndigheter-frestas-att-radera-mejl][In Swedish] 